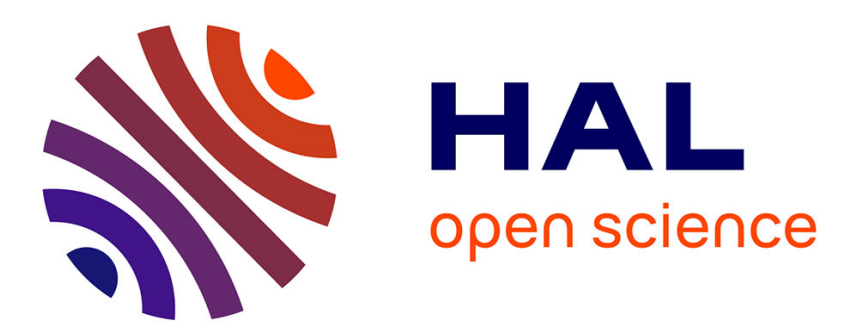

\title{
Leaching mechanisms of industrial powders of spent nickel metal hydride batteries in a pilot-scale reactor
}

Margot Zielinski, Laurent Cassayre, Philippe Destrac, Nicolas Coppey, Gilles Garin, Béatrice Biscans

\section{- To cite this version:}

Margot Zielinski, Laurent Cassayre, Philippe Destrac, Nicolas Coppey, Gilles Garin, et al.. Leaching mechanisms of industrial powders of spent nickel metal hydride batteries in a pilot-scale reactor. ChemSusChem, 2020, 13 (3), pp.616-628. 10.1002/cssc.201902640 . hal-02770455

\section{HAL Id: hal-02770455 https://hal.science/hal-02770455}

Submitted on 4 Jun 2020

HAL is a multi-disciplinary open access archive for the deposit and dissemination of scientific research documents, whether they are published or not. The documents may come from teaching and research institutions in France or abroad, or from public or private research centers.
L'archive ouverte pluridisciplinaire HAL, est destinée au dépôt et à la diffusion de documents scientifiques de niveau recherche, publiés ou non, émanant des établissements d'enseignement et de recherche français ou étrangers, des laboratoires publics ou privés. 


\section{Open Archive Toulouse Archive Ouverte}

OATAO is an open access repository that collects the work of Toulouse researchers and makes it freely available over the web where possible

This is an author's version published in: https://oatao.univ-toulouse.fr/26082

\section{Official URL:}

https://doi.org/10.1002/cssc.201902640

\section{To cite this version:}

Zielinski, Margot $\leftrightarrows$ and Cassayre, Laurent $\leftrightarrows$ and Destrac, Philippe Coppey, Nicolas and Garin, Gilles and Biscans, Béatrice $\stackrel{\sqcup}{2 \text { Leaching }}$ mechanisms of industrial powders of spent nickel metal hydride batteries in a pilotscale reactor. (2020) ChemSusChem, 13 (3). 616-628. ISSN 1864-5631.

Any correspondence concerning this service should be sent to the repository administrator: tech-oatao@listes-diff.inp-toulouse.fr 


\title{
Leaching Mechanisms of Industrial Powders of Spent Nickel Metal Hydride Batteries in a Pilot-Scale Reactor
}

\author{
Marg ot Zielinski, ${ }^{[a, b]}$ Laurent Cassayre, ${ }^{[a]}$ Philippe Destrac, ${ }^{[a]}$ Nicolas Coppey, ${ }^{[b]}$ Gilles Garin, ${ }^{[b]}$ \\ and Béatrice Biscans* ${ }^{*[a]}$
}

In view of a sustainable recycling process, the leaching mechanisms of nickel and rare-earth elements (REEs) contained within industrial samples of spent nickel metal hydride battery powders were investigated in $\mathrm{HCl}$ and $\mathrm{H}_{2} \mathrm{SO}_{4}$ under mild temperature $\left(25-60^{\circ} \mathrm{C}\right)$ and $\mathrm{pH}(3-5.5)$. First, in-depth characterization of the heterogeneous battery powder was carried out with powder XRD, SEM, electron probe microanalyzer wavelength-dispersive spectroscopy (EPMA-WDS) quantitative analyses of individual particles, and inductively coupled plasma optical emission spectrometry (ICP-OES) elemental analysis. An un- usual result is the identification of particles that exhibit a coreshell structure, which is related to anode active mass aging mechanisms. Then, a leaching study in a $10 \mathrm{~L}$ pilot-scale reactor demonstrated the selective dissolution of REEs, with respect to nickel, at $\mathrm{pH} 3$, which is attributed to 1) the kinetic inhibition of nickel metal dissolution, and 2) the specific coreshell structure of aged mischmetal particles. Furthermore, the use of $\mathrm{H}_{2} \mathrm{SO}_{4}$ led to coprecipitation of lanthanide-alkali double sulfates and nickel salts.

\section{Introduction}

Securing access to specialty metals required for high-performance technologies and energy materials has raised environmental and economic concerns in the past decade. Avoiding risks of supply shortages has become a major challenge for highly import-dependent economies, such as the EU! (1) This is particularly true for light rare-earth elements (REEs), for which China supplies over $95 \%$ of the world's production, according to the 2017 European Commission report on Critical Raw Materials." ${ }^{\text {"] }}$ Developing traditional mine production of such critical minerals in the EU depends on long-term investment projects that are not flexible enough towards rapid changes in market demands. "I) On the other hand, recycling of waste electric and electronic equipment (WEEE) or renewable energy materials in the EU can serve as an attractive secondary source of raw materials. For instance, the inner content of nickel metal hydride (NiMH) batteries, which are mainly used for hybrid or pure electric vehicles (HEV or PEV), consists of about $50 \mathrm{wt} \%$ nickel ${ }^{[2]}$ and 15 wt \% REEs. ${ }^{[3]}$ More than 1.8 million HEV battery units were sold worldwide in 2016, ${ }^{[4]}$ with an average battery collection rate of $44 \%$ in the EU that same year, ${ }^{[5]}$ and thus, assuring a significant feed for the recycling market. However, the

[a] M. Zielinski, Dr. L. Cassayre, P. Destac, Dr. B. Biscans Laboratoire de Génie Chimique Université de Toulouse, CNRS, INPT, UPS Toulouse (France) E-mail:beatrice.biscans@toulouse-inp.fr

[b] M. Zielinski, Dr. N. Coppey, Dr. G. Garin Société Nouvelle d'Affinage des Métaux (S.N.A.M.) Viviez (France) contribution of recycling to the market demand for critical materials is still relatively low because it is not yet technically nor economically feasible at the industrial scale. ${ }^{[6]}$ As a result, the end-of-life recycling rate of REEs is below $3 \%^{[1,7]}$ and the endof-life recycling input rate of nickel is only $25 \%$. ${ }^{16}$ The $50 \mathrm{wt} \%$ recycling efficiency target to be achieved for $\mathrm{NiMH}$ batteries, as described by the European Directive (2006/66/EC), makes it necessary for industries to develop more efficient and sustainable recycling schemes, and opens up new possibilities for urban mining. ${ }^{[8]}$

$\mathrm{NiMH}$ batteries are made up of four main components: an iron- or aluminum-based outer casing; anode and cathode current collectors, upon which active electrode powders are deposited by using binders; an alkaline electrolyte, such as $\mathrm{KOH}$; and a microporous polymer separator. ${ }^{[9-12]}$ The cathode current collector consists of a dense metallic nickel mesh, whereas the cathode active mass is made of spherical particles of either nickel hydroxide $\beta-\mathrm{Ni}(\mathrm{OH})_{2}$ or oxyhydroxide $\mathrm{NiO}(\mathrm{OH})$, depending on the state of charge of the battery. ${ }^{(13,14]}$ The anode typically contains a nickei-plated steel support as the current collector ${ }^{[13]}$ and an active mass consisting of a hydride alloy of varying compositions. The structure of hydrogen storage alloys can either be $A B_{s}$, in which $A=L a, N d, P r, C e$, or $Y$ and $B=N i$, $\mathrm{Co}, \mathrm{Mn}$, or $\mathrm{Al} ; A B_{2}$, in which $A=\mathrm{Tl}$ or $\mathrm{Zr}$ and $\mathrm{B}=\mathrm{Ni}, \mathrm{Co}, \mathrm{Mn}, \mathrm{Al}$, $\mathrm{V}, \mathrm{Cr}$, or $\mathrm{Sn}$; or $\mathrm{A}_{2} \mathrm{~B}_{7}$, in which $A=\mathrm{Nd}$ or $\mathrm{Mg}$ and $\mathrm{B}=\mathrm{Ni}$ or Al. ${ }^{[13,15)}$ Such an intricate battery composition highlights the need for advanced recycling processes to recover the majority of valuable metal content.

Hydrometallurgical processes are the main altemative for recycling NiMH batteries, in which battery powders are generally leached in a mineral acid, such as $\mathrm{HCl}^{[13,16-23]}$ (around $40 \%$ of the recent literature) or $\mathrm{H}_{2} \mathrm{SO}_{4}$ (about $60 \%$ ). ${ }^{(2,3,28-32,10,12,14,1824-27)}$ 
To a minor extent, a few researchers have studied the use of $\mathrm{HNO}_{3}{ }^{[13,29]}$ carboxylic acids, ${ }^{[12,21]}$ or ascorbic acid as leaching agents, but these have not been considered in this study. It is crucial to control the leaching step because the content of dissolved metals in solution will have a direct impact on subsequent recovery methods, such as precipitation or solvent extraction. Most of the literature on the leaching of spent $\mathrm{NiMH}$ batteries focuses on the impact of various operating parameters, such as type and concentration of acid, temperature, time, mixing speed, and addition of an oxidant. A nearly total dissolution of nickel and REEs is commonly sought-after, and thus, requires the use of aggressive leaching conditions: either high working temperatures $\left(70-95^{\circ} \mathrm{C}\right)$ or high acid concentrations (8-12 M). However, in view of more sustainable NiMH battery recycling processes, it is interesting to find milder leaching conditions. Although recent studies have been carried out in this regard, ${ }^{[13,21,23]}$ it is still necessary to better understand the particle leaching mechanisms at stake.

Moreover, at the industrial scale, spent $\mathrm{NiMH}$ batteries undergo specific head-end steps before leaching, such as thermolysis, milling, and sieving. Indeed, spent battery packs are first collected and sorted according to their type. Then they are processed through a heat treatment under a controlled atmosphere (thermolysis) to remove volatile organic components and make the batteries electrically inert. The material is then milled and sieved to obtain a powder enriched in valuable elements, such as nickel and REEs. These processing steps impact on both the chemical and physical properties of the starting material, and might consequently influence the leaching process. However, apart from a few studies, ${ }^{[10,12,14,33]}$ the initial material in most reports in the literature comes from manually dismantled batteries that have not gone through these pretreatment steps.

The aim of this work is, therefore, to provide a better understanding of the leaching behavior of nickel and REEs from industrial powders of spent NiMH batteries, the so-called black mass (BM) powder. The originality of this research lies in the fact that we have carried out in-depth particle characterization of a heterogeneous material with respect to that found at the industrial scale. The methodology applied for initial material characterization was then transferred to the analysis of solid leach residue, which was obtained from leaching experiments carried out in a $10 \mathrm{~L}$ pilot-scale reactor. Furthermore, to consider a more sustainable process at the industrial scale, we selected mild temperature $\left(25^{\circ} \mathrm{C}<T<60^{\circ} \mathrm{C}\right)$ and $\mathrm{pH}(3<\mathrm{pH}<5.5)$ operating conditions for the leaching experiments, in two acid media $\left(\mathrm{HCl}\right.$ and $\left.\mathrm{H}_{2} \mathrm{SO}_{4}\right)$.

\section{Results}

\section{BM powder characterization}

An industrial sample of approximately $600 \mathrm{~kg}$ of mixed types of spent NiMH batteries was collected. The battery packs, which were composed of a mixture of anodes, cathodes, and casing materials, were processed at industrial facilities. They were dismantled, thermolyzed in an oven, crushed by knife milling, and sieved at $<1 \mathrm{~mm}$. The resulting powder, BM, was carefully characterized before being used as a starting material for the leaching study.

\section{Chemical composition and phase analysis}

The average chemical composition of four samples of industrial BM powder from the same batch is provided in Table 1 (see the Experimental Section for all analytical details). The BM powder is mainly composed of $45.0 \mathrm{wt} \% \mathrm{Ni}$, approximately 15.9 wt \% REEs (La, Ce, Nd, Pr), 13.1 wt \% O, 5.4 wt \% Co, and

\begin{tabular}{|ll|}
\hline $\begin{array}{l}\text { Table 1. Average chemical composition [wt \%] of the industrial BM } \\
\text { sample powder. }\end{array}$ \\
\hline Element & Chemical composition [wt \%] \\
\hline Al & $0.85 \pm 0.01$ \\
Cd & $0.83 \pm 0.05$ \\
Co & $5.45 \pm 0.23$ \\
Cu & $0.51 \pm 0.03$ \\
Fe & $2.90 \pm 0.32$ \\
K & $2.17 \pm 0.07$ \\
$\mathrm{Li}$ & $0.13 \pm 0.01$ \\
$\mathrm{Mn}$ & $2.37 \pm 0.14$ \\
$\mathrm{Na}$ & $<$ detection limit \\
$\mathrm{Zn}$ & $1.56 \pm 0.19$ \\
$\mathrm{Ni}$ & $44.98 \pm 0.69$ \\
$\mathrm{La}$ & $8.72 \pm 0.22$ \\
$\mathrm{Ce}$ & $5.02 \pm 1.09$ \\
$\mathrm{Nd}$ & $1.68 \pm 0.05$ \\
$\mathrm{Pr}$ & $0.45 \pm 0.01$ \\
$\mathrm{O}$ & $13.1 \pm 0.1$ \\
$\mathrm{C}$ & 2.83 \\
total & 93.65 \\
& \\
\hline & \\
\hline
\end{tabular}

$2.4 \mathrm{wt} \% \mathrm{Mn}$. Although the contents of Co and $\mathrm{Mn}$ in the BM powder are significant and these metals have a noticeable economic value, herein we have chosen to report only results for the major elements $\mathrm{Ni}$ and REEs. The presence of $\mathrm{K}(2.2 \mathrm{wt} \%)$ is attributed to residual $\mathrm{KOH}$ electrolyte. Sodium is absent from the BM (below the detection limit), and traces of cadmium and lithium are due to cross contamination from other types of batteries during the manual battery-sorting step. Elemental carbon ( $2.8 \mathrm{wt} \%$ ) most likely comes from the residue of organic components formed during heat treatment of the batteries. A total chemical composition of $93.65 \mathrm{wt} \%$ is obtained; the missing mass can be explained by the fact that additional elements such as Y or Sm have not been analyzed and that a small quantity of BM could not be dissolved prior to elemental analysis.

The powder X-ray diffractogram (Figure S1 in the Supporting Information) provides evidence of the presence of $\mathrm{Ni}, \mathrm{NiO}$, $\mathrm{CeO}_{2}$, and graphite as major phases. Minor phases include $\mathrm{CO}_{3} \mathrm{La}_{2}$ and $\mathrm{La}_{7} \mathrm{Ni}_{16}$; other rare-earth-containing phases could not be identified due to the detection limit of the technique. 


\section{Local elemental particle characterization}

Although local electron probe microanalyses (EPMA) infer that both the morphology and associated chemical composition of the BM particles are very heterogeneous, our observations lead us to propose a classification into five main categories of particles.

P1-type particles observed and characterized by means of scanning electron microscopy energy-dispersive X-ray spectroscopy (SEM-EDX; not shown herein) consist of individual iron oxide and aluminum oxide particles, with a characteristic dimension of about $30 \mu \mathrm{m}$, possibly originating from the outer casing of the battery.

As shown in Figure 1, zone 1, P2-type particles containing around 97 at $\% \mathrm{Ni}$ were evidenced (Table 2). They come from the metallic nickel mesh of the cathode current collector and correspond to the nickel phase identified by means of powder XRD.

P3-type particles consist of circular porous particles, single or agglomerated, that contain, on average, 78.0 at $\% \mathrm{Ni}$, 5.3 at $\%$ Co, and 4.8 at \% O (Figure 1, zone 2, and range of compositions in Table 2). Given their morphology, it can be stipulated that P3-type particles come from the active mass of the
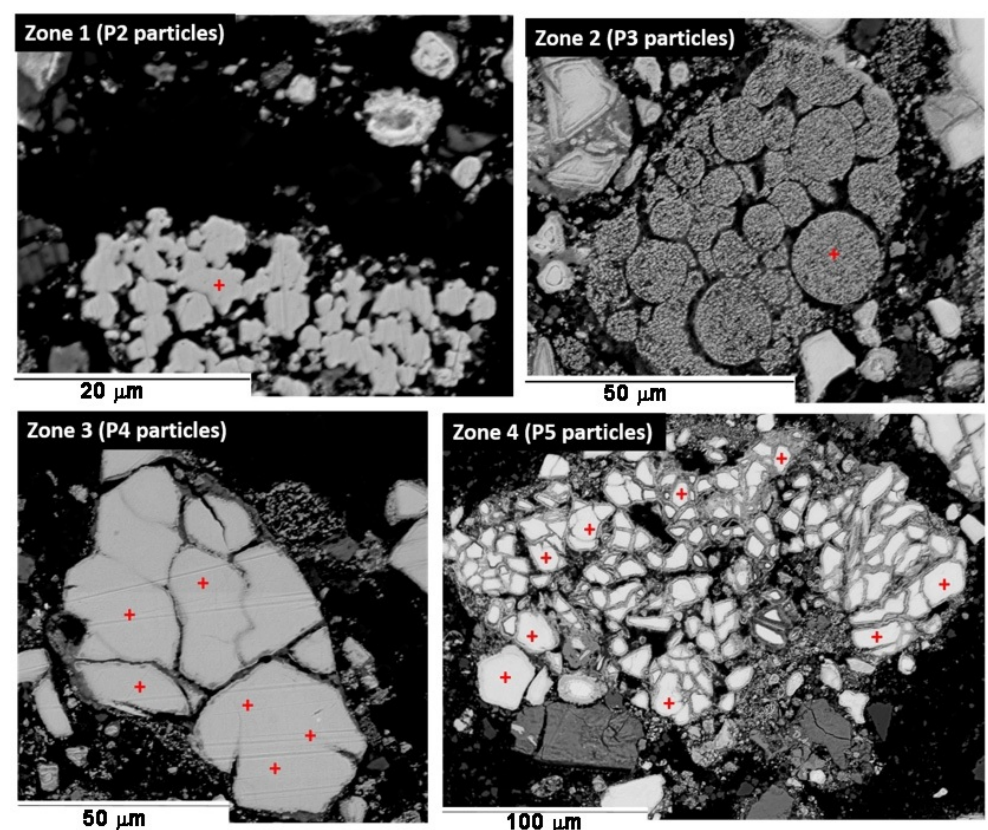

Figure 1. SEM backscattered electron (BSE) cross sections of representative BM particles: P2 type (zone 1), P3 type (zone 2), P4 type (zone 3 ), and P5 type (zone 4). cathode, which are originally spherical $\mathrm{Ni}(\mathrm{OH})_{2}$ or $\mathrm{NiO}(\mathrm{OH})$ particles, depending on the state of charge of the battery, although a higher oxygen content would be expected.

Particles rich in REEs have been categorized as either of P4 or P5 type. As shown in Figure 1, zone 3, P4-type particles exhibit a geometric shape with a dense and smooth external surface. EPMA point analyses on several P4 particles give molar ratios of $(\mathrm{Ni}, \mathrm{Co}, \mathrm{Mn}, \mathrm{Al}) /(\mathrm{La}, \mathrm{Ce}, \mathrm{Nd}, \mathrm{Pr})$ in the range of 1.9 and 4.6 (Table 2). The specific Ni/La molar ratio of 2.20 obtained for some P4-type particles is almost equivalent to that of the $\mathrm{La}_{7} \mathrm{Ni}_{16}$ phase identified by means of powder XRD. On the other hand, P5-type particles shown in Figure 1, zone 4, exhibit a core-shell structure; the core is composed of 38.0 at $\% \mathrm{Ni}$, 34.9 at $\%$ O, and 4.1 at \% La on average. The (Ni, Co, Mn, Al)/ $(\mathrm{La}, \mathrm{Ce}, \mathrm{Nd}, \mathrm{Pr}$ ) molar ratios of P5-type particles are in the range of 3.8 and 4.9 (Table 2). The range of compositions found for P4- and P5-type particles can be attributed to the heterogeneity of the initial material; the sample is composed of different types of spent NiMH batteries.

A high-magnification cross section of a P5-type particle with a representative core-shell structure and corresponding EPMA line profile are shown in Figure 2. Around the core (the lighter part on the micrographs), the shell is composed of a dense, thin layer (Figure $2 \mathrm{~b}$ ) covered by a porous matrix. The EPMA line profile (Figure $2 \mathrm{~d}$ ) reveals that the dense layer of the shell (the two points at 1.8 and $3.5 \mu \mathrm{m})$ contains, on average, 1.35 times more $\mathrm{Ni}$ and Co than that in the core (points at $<1.8$ and $>4.7 \mu \mathrm{m}$ ). As for the porous matrix (point at $3.0 \mu \mathrm{m}$ ), it has high contents of $\mathrm{La}, \mathrm{Ce}$, and $\mathrm{O}$ of 23.9, 8.1, and 20.1 at \%, respectively, whereas the $\mathrm{Ni}$ and Co contents drop to 8.8 and 1.1 at\%, respectively (Figure $2 \mathrm{~d}$ ).

The core-shell structure of P5-type particles is most likely linked to NiMH battery aging mechanisms. Indeed, the degradation of NiMH batteries is a complex process in which different mechanisms are at play, including corrosion of the hydrogen storage alloy. It is worth noting that the stability of the mischmetal alloy against corrosion can be impacted by the chemical composition of the alloy, among other parameters. According to the groups of Leblanc and Bäuerlein, changes in corrosion rates as a function of alloy composition are mainly due to differences in decrepitation tendencies. ${ }^{[34,35]}$ Decrepitation, or particle pulverization, is caused by lattice expansion and contraction of the alloy during hydrogen absorption

\begin{tabular}{|c|c|c|c|c|c|c|c|c|c|c|c|c|c|}
\hline \multirow[t]{2}{*}{ Particle type } & \multicolumn{12}{|c|}{ Atomic content [\%] } & \multirow[t]{2}{*}{$(\mathrm{Ni}, \mathrm{Co}, \mathrm{Mn}, \mathrm{Al}):(\mathrm{REEs})$} \\
\hline & $\mathrm{O}$ & $\mathrm{Al}$ & $\mathrm{K}$ & $\mathrm{Mn}$ & Co & & $\mathrm{Ni}$ & $\operatorname{Pr}$ & $\mathrm{Nd}$ & La & $\mathrm{Ce}$ & Total & \\
\hline P2 & 1.21 .4 & 0 & 00.1 & 0.10 .2 & 0.3 & 0.9 & 97.497 .7 & 0 & 0 & 0 & 0 & 100 & \\
\hline P3 & 2.08 .1 & 0.20 .4 & 0.21 .4 & 0.10 .4 & 2.9 & 7.3 & 62.093 .6 & 0 & 0 & 0 & 0 & 92.0 & \\
\hline P4 & 9.533 .0 & 1.13 .0 & 00.2 & 3.74 .3 & 6.2 & 8.7 & 42.143 .6 & 0.3 & 1.42 .4 & 6.019 .8 & 3.28 .2 & 99.9 & 1.94 .6 \\
\hline P5 & $31.8 \quad 36.9$ & 2.84 .4 & 00.9 & 3.95 .4 & 5.8 & 7.8 & 35.641 .0 & 0.50 .6 & 1.42 .2 & 3.54 .7 & 4.76 .5 & 100 & 3.84 .9 \\
\hline
\end{tabular}




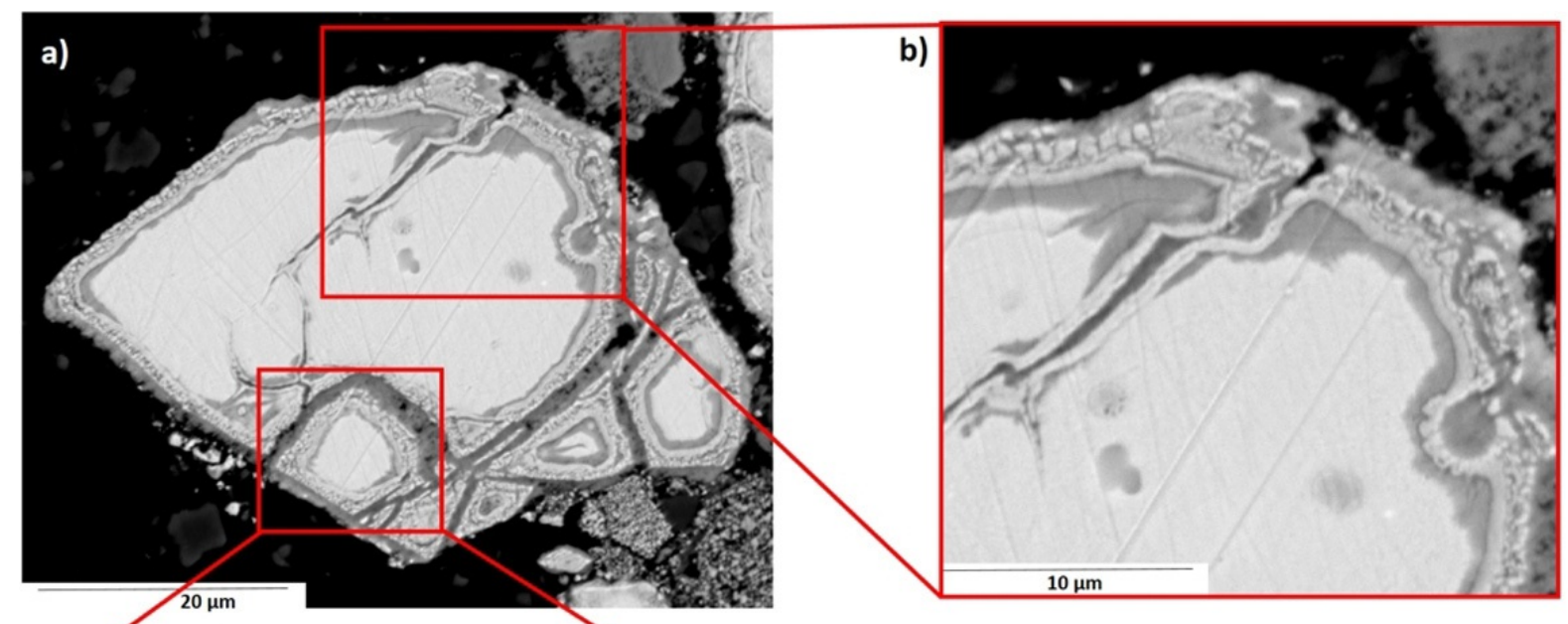

c)

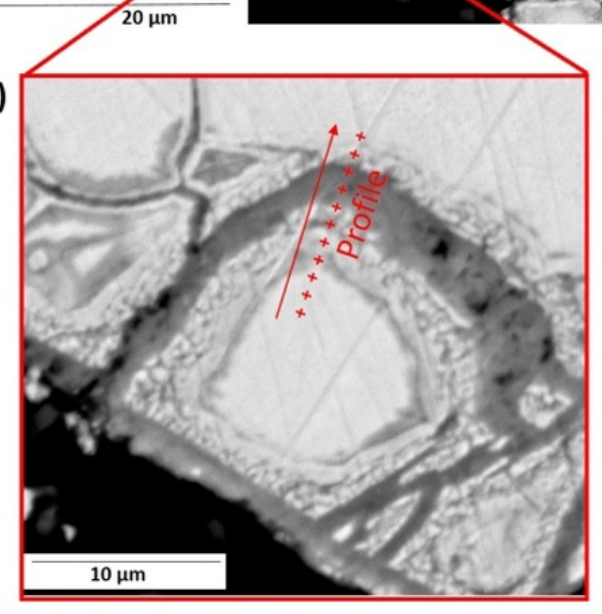

d)

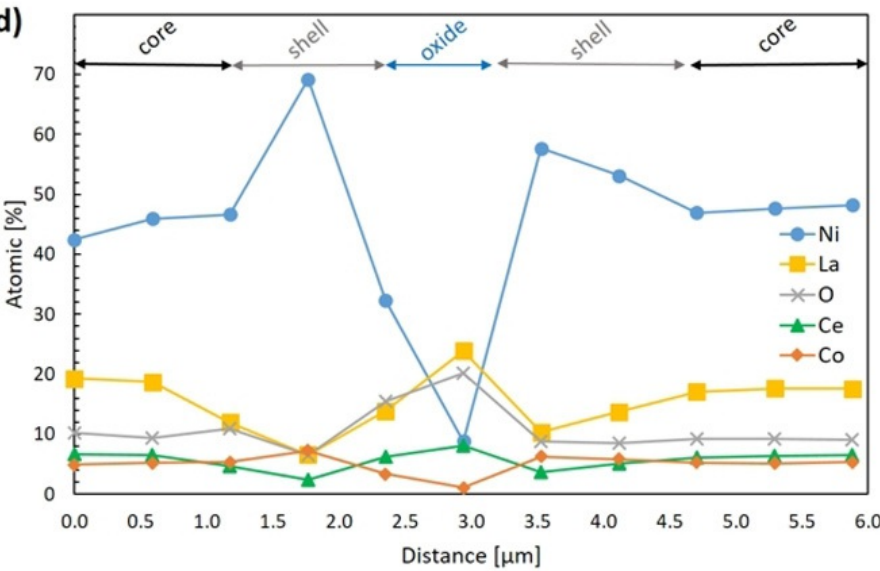

Figure 2. a) SEM BSE cross section of a P5 type BM particle with a core shell structure, b) first magnification of the core shell oxide structure, c) second mag nification of the core shell oxide structure, and d) corresponding EPMA WDS line profile [at \%].

and desorption. The discrete volume changes produce local mechanical stresses that lead to cracking of the alloy grains, the generation of smaller particles, and the development of a higher particle specific surface area. ${ }^{[34-36]}$ Knowing that, from a thermodynamic point of view, the oxidation of less noble metals, such as $\mathrm{La}, \mathrm{Nd}, \mathrm{Pr}$, and $\mathrm{Ce}$, in $\mathrm{KOH}$ cannot be avoided ${ }^{[36]}$ the higher the particle specific surface area the greater the amount of corrosion scales. Therefore, there is a correlation between the decrepitation tendency of the mischmetal alloy and the corrosion of the particles. Consequently, alloy composition can be optimized to achieve low lattice expansions during hydrogen intercalation. For example, Chartouni et al. stated that cobalt substitution in the mischmetal alloy had a stabilizing effect by reducing the cracking tendency of the alloy. ${ }^{[37]}$

Several studies in the literature report that corrosion scales form at the surface of the particles in strong-alkali media, retarding hydrogen diffusion rates and leading to battery failure. ${ }^{[15,21,34-36,38-40]}$ Maurel et al. analyzed TEM cross sections of $\mathrm{AB}_{5}$ mischmetal cycled in $\mathrm{KOH}$ electrolyte, and suggested the formation of three different corrosion layers due to solid-state diffusion: a metallic core different from that of the initial alloy, a continuous corrosion subscale up to $200 \mathrm{~nm}$ thick composed of solid solutions of $\mathrm{Ni}$ and $\mathrm{Co}$, and a surface layer of rareearth hydroxide composed of $1.5 \mu \mathrm{m}$ long needles embedded in the corrosion subscale. ${ }^{[36]}$ Nickel and cobalt sublayers were also identified by the groups of $1 \mathrm{koma}^{[38]}$ and Bäuerlein, ${ }^{[35]}$ and several other authors indicated that needle-shaped rare-earth hydroxides covered the surface of the alloy upon battery cycling in alkali media. ${ }^{[15,34-36,38]}$

Based on these consistent observations, we postulate that P4-type particles correspond to unused battery material (Figure 1, zone 3), whereas the core-shell structure of P5-type particles identified in the BM correspond to aged alloys (Figure 1, zone 4, and Figure 2). The nickel and cobalt sublayer identified in the literature corresponds to the dense layer of the shell of P5-type particles shown in Figure 2. The porous matrix rich in $\mathrm{La}, \mathrm{Ce}$, and $\mathrm{O}$ observed around $\mathrm{P} 5$-type particles (Figure 2c) may thus originate from the disintegration of the needle-like rare-earth hydroxide surface layer. Moreover, based on the observation of various cross sections of the BM samples, there are proportionally many more P5-type particles than that of P4-type particles, which is consistent with the fact that most batteries are collected if fully spent.

On top of structural changes caused by corrosion of the anode during battery cycling, the thermolysis step is very likely 
to induce structural and chemical evolutions of the mischmetal alloy. However, the impact of thermolysis linked to battery reprocessing is related to more recent concerns than those of battery aging, and thus, is not yet documented in the literature. Nevertheless, based on a thermodynamic study of the La Ni O ternary system by Zinkevich and Aldinger, it is very likely that thermolysis leads to the formation of the stable $\mathrm{La}_{2} \mathrm{NiO}_{4}$ spinel. ${ }^{[41]}$ Indeed, this lanthanum nickelate is stable over a large range of oxygen partial pressure (typically $10^{-8}$ atm $<P_{\mathrm{O}_{2}}<10^{-1} \mathrm{~atm}$ ), covering thermolysis operating conditions. For $\mathrm{Ni} /(\mathrm{Ni}, \mathrm{La})$ molar ratios greater than 0.5 , the phase diagram indicates that the spinel phase is the first phase that forms from the oxidation of a Ni La alloy, followed by oxidation of nickel into $\mathrm{NiO}$. The results of Zinkevich et al. could explain both the high oxygen content observed at the core of P5-type particles (Table 2 and Figure $2 \mathrm{~d}$ ) and the $\mathrm{NiO}$ phase detected by means of powder XRD. ${ }^{[41]}$

Altogether, the EPMA characterization is coherent with the initial constitution of NiMH batteries, and particles from the anode and cathode active mass, as well as current collectors have been identified and quantified. Thanks to this local particle identification approach, it is thus possible to follow the leaching progress by comparing the particles identified in the initial BM powder with those in the solid leach residue over time.

\section{Thermodynamic-based choice of $\mathrm{pH}$ for leaching experi- ments in $\mathrm{HCl}$ media}

The choice of $\mathrm{pH}$ for leaching experiments in $\mathrm{HCl}$ was guided by thermodynamic calculations. Considering the complex phase composition of the initial BM powder, the system was restricted to the system $\mathrm{Ni}-\mathrm{La}-\mathrm{H}_{2} \mathrm{O}-\mathrm{HCl}$ because $\mathrm{Ni}$ and $\mathrm{La}$ are the major elements in the BM. The Eh-pH diagrams calculated at $40^{\circ} \mathrm{C}$ for $\mathrm{La}$ and $\mathrm{Ni}$ are presented in Figure $3 \mathrm{a}$ and $\mathrm{b}$, together with the list of aqueous species and solid phases taken into account in Figure 3 c. Calculation details are provided in the Experimental Section.
As observed in Figure $3 \mathrm{a}$, La is not stable in its metallic form in aqueous media. At $\mathrm{pH} \leq 6.8$ and $40^{\circ} \mathrm{C}$ (or $\mathrm{pH} \leq 7.1$ at $25^{\circ} \mathrm{C}$; $\mathrm{pH} \leq 6.3$ at $60^{\circ} \mathrm{C}$ ), $\mathrm{La}$ is fully dissolved, mainly as $\mathrm{LaCl}^{2+}$. At higher $\mathrm{pH}$, its stable form is the solid hydroxide $\mathrm{La}(\mathrm{OH})_{3}$.

As for $\mathrm{Ni}$ (Figure $3 \mathrm{~b}$ ), a lower $\mathrm{pH}$ is required to ensure its full dissolution $\left(\mathrm{pH} \leq 4.2\right.$ at $40^{\circ} \mathrm{C}$ ) and $\mathrm{Ni}^{2+}$ is the aqueous dominant species for all temperatures; the complex $\mathrm{NiCl}^{+}$is present to a minor degree. Above $\mathrm{pH} 4.2$ at $40^{\circ} \mathrm{C}$, metallic nickel is stable and is not oxidized by $\mathrm{H}^{+}$ions. Nickel(II) is soluble up to $\mathrm{pH} 6$, and forms the solid hydroxide $\mathrm{Ni}(\mathrm{OH})_{2}$ at higher $\mathrm{pH}$.

Notably, solids composed of both $\mathrm{Ni}$ and La elements $\left(\mathrm{LaNi}_{5}\right.$ and $\mathrm{La}_{2} \mathrm{NiO}_{4}$ ) do not appear on these diagrams, which means that the main mixed phases of the battery are not stable under leaching conditions.

These preliminary calculations indicate that, for a solid/liquid $(\mathrm{S} / \mathrm{L})$ ratio of $15 \mathrm{wt} \%$, both nickel and lanthanum elements should be soluble at $\mathrm{pH} 4$ and below, regardless of their initial redox state. At $4<\mathrm{pH}<6$, La and $\mathrm{Ni}^{\prime \prime}$ are soluble, but metallic $\mathrm{Ni}$ is stable. At $6<\mathrm{pH}<6.8$, La is stable in the aqueous phase, whereas all redox states of $\mathrm{Ni}$ are involved in solid phases. Above $\mathrm{pH} 6.8$, no dissolution of these two major elements in the BM should occur. These calculations imply a strong influence of $\mathrm{pH}$ on the leaching behavior of the $\mathrm{BM}$, and suggest that tuning the $\mathrm{pH}$ value might allow the selective dissolution of La. Therefore, the influence of $\mathrm{pH}$ on leaching of the BM was studied over the $\mathrm{pH}$ range of 3 to 5.5 , and $\mathrm{pH} 3$ was used as a point of comparison for studying the influence of the type of acid $\left(\mathrm{HCl}\right.$ or $\left.\mathrm{H}_{2} \mathrm{SO}_{4}\right)$ on the leaching yields and rates with respect to temperature.

\section{Leaching experiment results}

As detailed in the Experimental Section, BM leaching experiments were carried out in a $10 \mathrm{~L}$ pilot reactor. The results are presented in the following sections, starting with the influence of temperature, then $\mathrm{pH}$, and finally the nature of the acid.
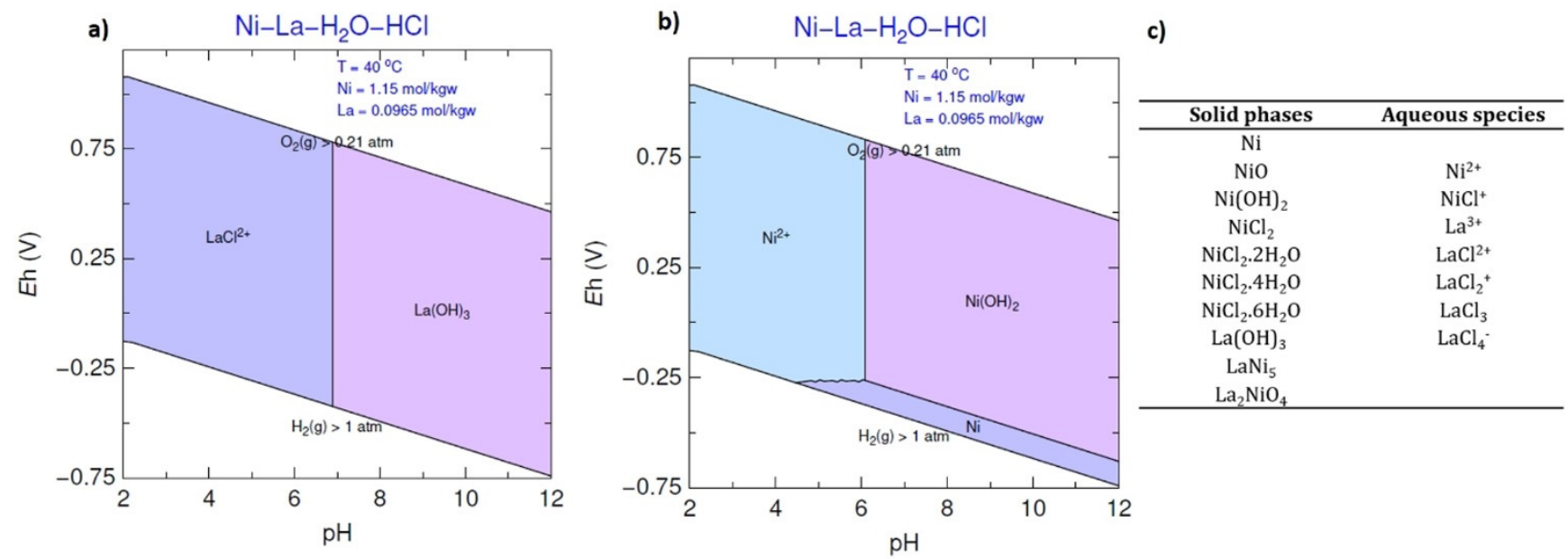

Figure 3. Calculated $\mathrm{Eh} \mathrm{pH}$ diagram for a) La and b) $\mathrm{Ni}$, in the quaternary system $\mathrm{Ni} \mathrm{La} \mathrm{H}_{2} \mathrm{O} \mathrm{HCl}$ at $40^{\circ} \mathrm{C}$, with [La] $=0.0965$ molkgw ${ }^{1}$ (kilograms of water) and $[\mathrm{Ni}]=1.15 \mathrm{~mol} \mathrm{kgw}^{1}$ (S/L ratio of $\left.15 \mathrm{wt} \%\right)$. c) List of the solid phases and aqueous species considered for thermodynamic calculations. 


\section{Influence of temperature}

The influence of temperature on the leaching yields of La and $\mathrm{Ni}$ in $\mathrm{HCl}$ at $\mathrm{pH} 3$ is shown in Figure $4 \mathrm{a}$; similar behavior to that of $\mathrm{La}$ is obtained for $\mathrm{Ce}, \mathrm{Nd}$, and $\mathrm{Pr}$. The experiment at $40^{\circ} \mathrm{C}$ was repeated twice and demonstrated good repeatability of the leaching yields and total acid consumption: a difference of less than 3.1 and $5.4 \%$ for the leaching yields of $\mathrm{Ni}$ and $\mathrm{La}$, respectively, and a relative difference of $1.2 \%$ for the acid consumption were obtained between both experiments after $6 \mathrm{~h}$ of leaching.

Regardless of the temperature, La (and other REEs) leaching yields increase gradually and converge to complete dissolution (Figure $4 \mathrm{a}$ ) after $22 \mathrm{~h}$. As for $\mathrm{Ni}$, a leaching yield of $58 \%$ is reached after $22 \mathrm{~h}$ at $60^{\circ} \mathrm{C}$, and the yield decreases with temperature. The leaching in $\mathrm{HCl}$ at $\mathrm{pH} 3$ is thus partially selective: a maximal La/Ni selectivity ratio of about 6.5 is obtained for all three temperatures, and the time at which this maximum is
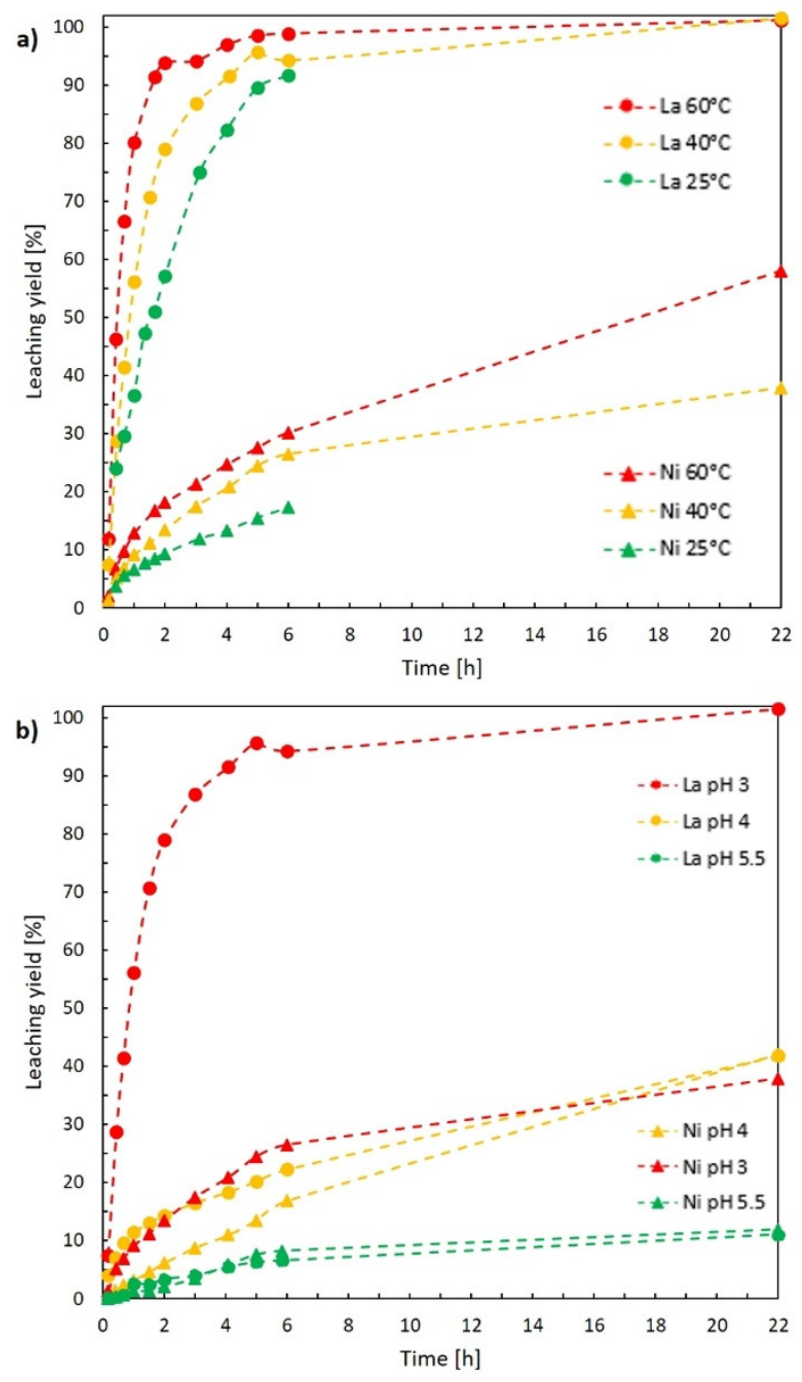

Figure 4. a) Influence of the temperature in $\mathrm{HCl}$ at $\mathrm{pH} 3$ on the leaching yields of $\mathrm{La}$ (circles) and $\mathrm{Ni}$ (triangles). b) Influence of the $\mathrm{pH}$ in $\mathrm{HCl}$ at $40^{\circ} \mathrm{C}$ on the leaching yields of La (circles) and Ni (triangles).

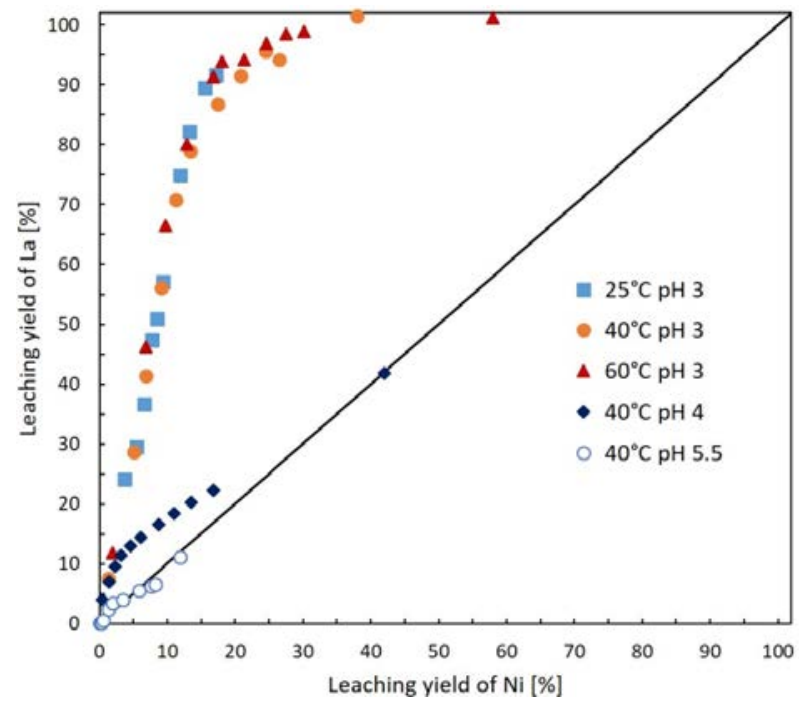

Figure 5. Leaching yield of La [\%] expressed with respect to the leaching yield of $\mathrm{Ni}[\%]$ for experiments carried out in $\mathrm{HCl}$ at various $\mathrm{pH}$ and tempera ture (the black line corresponds to a congruent dissolution of $\mathrm{La}$ and $\mathrm{Ni}$ ).

reached greatly reduces with temperature (after $3 \mathrm{~h}$ at $25^{\circ} \mathrm{C}$, $1.5 \mathrm{~h}$ at $40^{\circ} \mathrm{C}$, and $36 \mathrm{~min}$ at $60^{\circ} \mathrm{C}$ ). The evolution of the leaching yield of $\mathrm{La}$ with respect to that of $\mathrm{Ni}$ at $\mathrm{pH} 3$ is plotted in Figure 5. Considering that, thermodynamically, both $\mathrm{La}$ and $\mathrm{Ni}$ are soluble in $\mathrm{HCl}-\mathrm{H}_{2} \mathrm{O}$ under these conditions (Figure 3), the fact that all experimental points are located above the bisecting line shows that the leaching kinetics of REEs are faster than that of Ni. Moreover, all experimental points at $\mathrm{pH} 3$ overlap, which demonstrates a similar leaching mechanism, regardless of temperature. At $\mathrm{pH} 3$ in $\mathrm{HCl}$, the temperature only enhances the overall reaction kinetics and an increase of $35^{\circ} \mathrm{C}$ (from 25 to $60^{\circ} \mathrm{C}$ ) decreases the leaching duration by a factor of about 3.

Evolution of the chemical composition of the solid leach residues after mineralization (Table S1 in the Supporting Information) indicates an overall enrichment in $\mathrm{Ni}$ and a depletion in REEs, with respect to the initial BM powder, which is in agreement with the ICP-OES analyses of the pregnant leach solution (PLS). Powder XRD analysis of all solid leach residues shows that the major phases present in the initial BM powder are still present even after $22 \mathrm{~h}$ of leaching at $60^{\circ} \mathrm{C}$, namely, $\mathrm{Ni}, \mathrm{NiO}$, and graphite (Figure S2 in the Supporting Information).

It is interesting to identify P2- and P5-type particles in the solid leach residue, knowing that they are the ones which contain the highest contents of $\mathrm{Ni}$ and REEs. According to SEM and EPMA characterizations, many P2-type particles (pure Ni) are still present (Figure 6, zone 5) in the solid leach residue after $22 \mathrm{~h}$ of leaching at $60^{\circ} \mathrm{C}$.

A striking observation is that the core-shell structures of P5type particles identified in the initial BM powder are still clearly apparent in all solid leach residues. After $1 \mathrm{~h}$ of reaction in $\mathrm{HCl}$ at $\mathrm{pH} 3$ and $60^{\circ} \mathrm{C}$, that is, shortly after the maximum La/Ni selectivity ratio is reached, the composition and morphology of particles shown in Figure 6, zones 1 and 2, illustrate the leaching mechanism. According to the EPMA wavelength-dispersive 


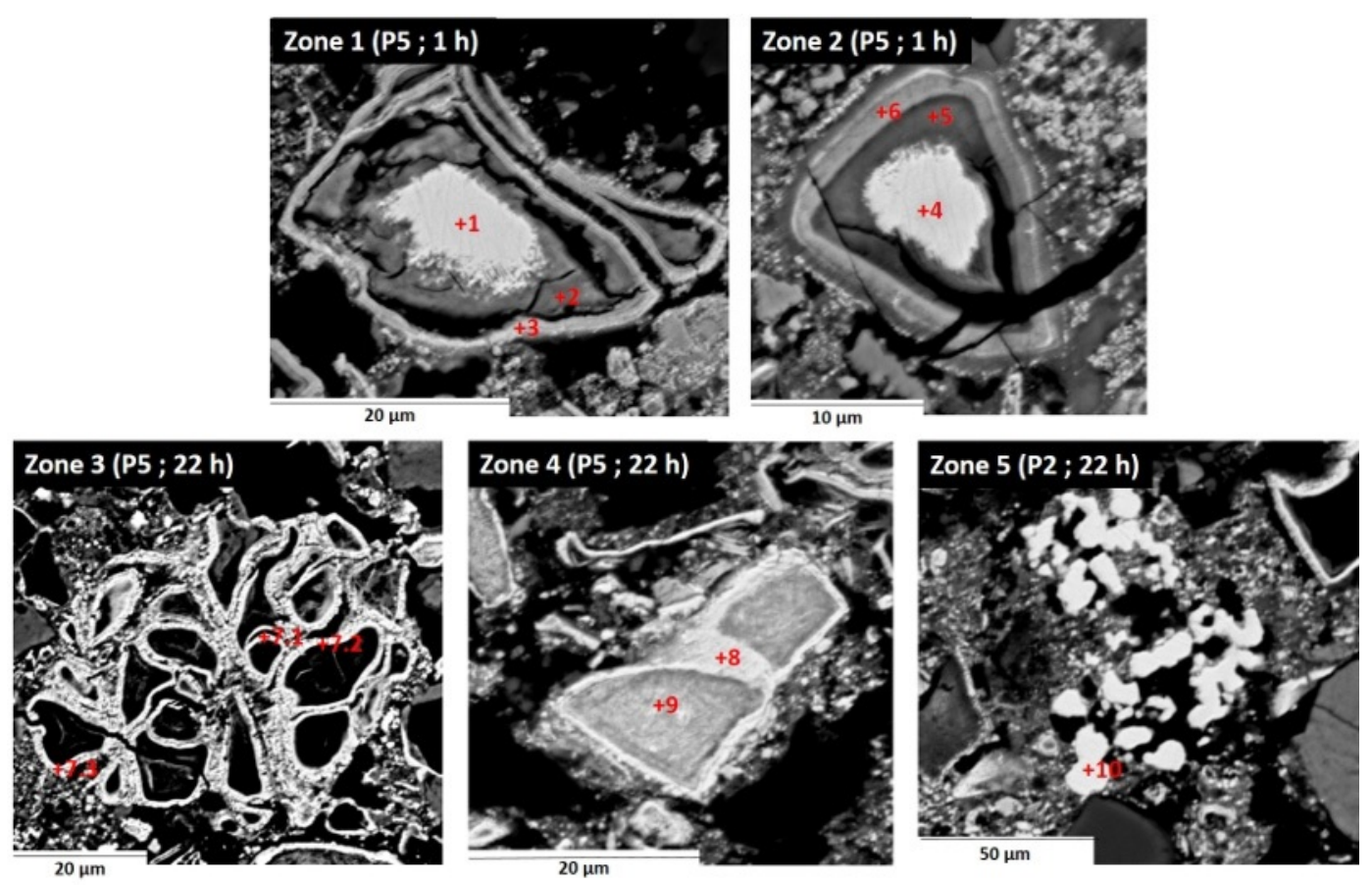

Figure 6. SEM BSE cross sections of particles in the solid leach residue obtained in $\mathrm{HCl}$ at $\mathrm{pH} 3$ and $60^{\circ} \mathrm{C}$, after $1 \mathrm{~h}$ of leaching (zones 1 and 2 ) and after $22 \mathrm{~h}$ of leaching (zones 3 5).

\begin{tabular}{|c|c|c|c|c|c|c|c|c|c|c|c|c|}
\hline \multirow[t]{2}{*}{ Region } & & \multicolumn{11}{|c|}{ Composition [at \%] } \\
\hline & & $\mathrm{O}$ & Al & $\mathrm{K}$ & $\mathrm{Mn}$ & Co & $\mathrm{Ni}$ & $\operatorname{Pr}$ & $\mathrm{Nd}$ & La & $\mathrm{Ce}$ & Total \\
\hline \multirow{4}{*}{ zone 1} & 1 & 9.2 & 1.6 & 0.0 & 3.6 & 9.3 & 44.1 & 1.5 & 5.2 & 10.3 & 12.7 & 97.4 \\
\hline & 2 & 15.1 & 0.2 & 0.3 & 0.1 & 6.5 & 42.6 & 0.2 & 0.4 & 0.9 & 1.2 & 67.6 \\
\hline & 3 & 4.2 & 0.0 & 0.1 & 0.2 & 14.0 & 75.6 & 0.2 & 0.4 & 1.6 & 1.0 & 97.5 \\
\hline & 4 & 9.5 & 1.7 & 0.0 & 4.6 & 8.5 & 42.1 & 1.2 & 4.2 & 10.7 & 13.8 & 96.5 \\
\hline \multirow[t]{2}{*}{ zone 2} & 5 & 16.0 & 0.0 & 0.2 & 0.0 & 6.6 & 41.0 & 0.1 & 0.1 & 0.1 & 0.1 & 64.2 \\
\hline & 6 & 13.6 & 0.2 & 0.1 & 0.0 & 8.4 & 47.6 & 0.0 & 0.2 & 0.3 & 0.6 & 70.9 \\
\hline zone $3^{[a]}$ & 7 & 26.8 & 1.0 & 0.0 & 0.1 & 8.9 & 62.1 & 0.0 & 0.1 & 0.2 & 0.2 & 101.5 \\
\hline \multirow{2}{*}{ zone 4} & 8 & 24.5 & 0.9 & 0.0 & 0.1 & 9.6 & 63.2 & 0.0 & 0.1 & 1.1 & 0.5 & 100 \\
\hline & 9 & 40.4 & 0.8 & 0.1 & 0.1 & 7.2 & 50.0 & 0.0 & 0.1 & 0.9 & 0.5 & 100 \\
\hline zone 5 & 10 & 1.2 & 0.0 & 0.0 & 0.0 & 0.31 & 98.0 & 0.0 & 0.0 & 0.0 & 0.0 & 100 \\
\hline
\end{tabular}

spectroscopy (WDS) point analyses (Table 3, zone 1), the core of the dissolving particle contains about 30 at $\%$ REEs, whereas the intermediate layer and shell contain 2.6 and 3.3 at $\%$ REEs, respectively. Moreover, compared to the core, the shell of the particle contains high amounts of $\mathrm{Ni}(75.6$ at \%) and is enriched in Co (14.0 at\%; Figure 6, zone 1, and Table 3), which is close to the composition of the shell of P5-type particles in the initial BM powder (Table 2). An EPMA concentration profile measured across a larger particle (Figure 7) provides evidence that the shell contains between 70 and 90 at $\% \mathrm{Ni}$ and 10 and 20 at $\%$ REEs. Overall, these observations show that REEs dissolve preferentially to nickel from the core of the particles, and that nickel contained in the dense outer shell does not dissolve.

Such a leaching mechanism is also evidenced in the cross sections of the solid leach residue after $22 \mathrm{~h}$ of dissolution in
$\mathrm{HCl}$ at $\mathrm{pH} 3$ and $60^{\circ} \mathrm{C}$, where the structure of the remaining particles is either a porous shell with a hollow core (Figure 6, zone 3) or a core-shell structure with an undissolved core (Figure 6, zone 4). The shells of the hollow particles appear to be porous, and thus, allow REEs to dissolve. According to EPMA analyses (Table 3), the shells of these hollow particles are composed of approximately 62.1 at $\% \mathrm{Ni}, 8.9$ at \% Co, and less than 0.5 at \% REEs. The shells of the particles with an undissolved core have almost the same composition (Table 3), while their core contains 50.0 at \% Ni, 7.2 at \% Co, 40.4 at \% O, and less than 1.5 at $\%$ REEs. These results indicate that the shells and nickel-rich cores of the remaining particles, originally from the spent active mass of the anode, have very slow leaching kinetics in $\mathrm{HCl}$ at $\mathrm{pH} 3$, similarly to the metallic nickel mesh of the cathode. 

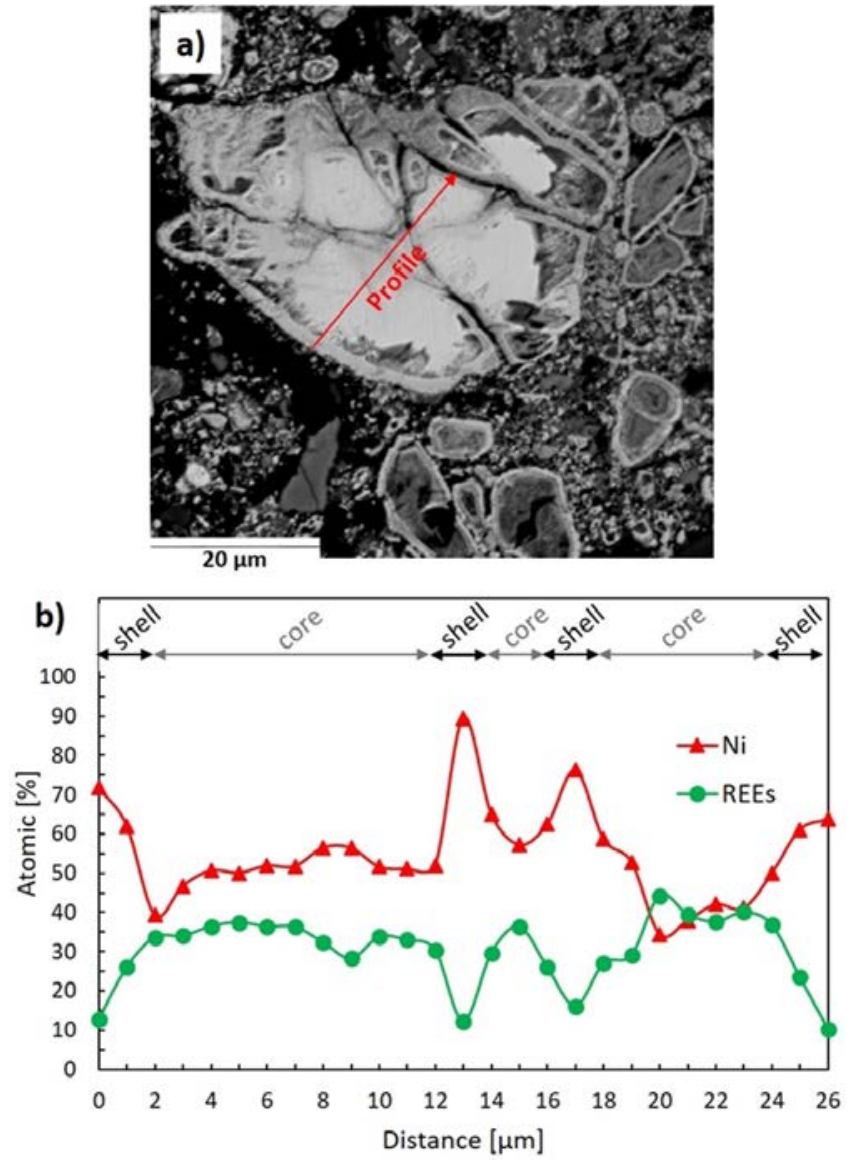

Figure 7. a) SME BSE cross section of a particle after $1 \mathrm{~h}$ of leaching in $\mathrm{HCl}$ at $\mathrm{pH} 3$ and $60^{\circ} \mathrm{C}$. b) Corresponding EPMA WDS concentration profile obtained across the particle [at \%].

\section{Influence of $\mathrm{pH}$}

The influence of $\mathrm{pH}$ on the evolution of the leaching yields of REEs and $\mathrm{Ni}$ in $\mathrm{HCl}$ at $40^{\circ} \mathrm{C}$ is shown in Figure $4 \mathrm{~b}$. After $22 \mathrm{~h}$ of leaching at $40^{\circ} \mathrm{C}$, the recovery yield of $\mathrm{Ni}$ decreases from $37.9 \%$ at $\mathrm{pH} 3$ to only $11.9 \%$ at $\mathrm{pH}$ 5.5. Meanwhile, the La recovery yield drops from $100 \%$ at $\mathrm{pH} 3$ to $11.1 \%$ at $\mathrm{pH}$ 5.5. Similar leaching behavior as $\mathrm{La}$ is obtained for $\mathrm{Ce}, \mathrm{Nd}$, and $\mathrm{Pr}$ at $\mathrm{pH} 3$ and 4, whereas at $\mathrm{pH} 5.5 \mathrm{Ce}, \mathrm{Nd}$, and $\mathrm{Pr}$ have lower leaching yields than that of La of $8.0,5.2$, and $4.4 \%$, respectively, after $22 \mathrm{~h}$ of leaching at $40^{\circ} \mathrm{C}$. As observed in Figure 5 , at $\mathrm{pH} 5.5$ and $40^{\circ} \mathrm{C}$, if the leaching yield of La is plotted against that of $\mathrm{Ni}$, the experimental points are almost aligned with the bisecting line. According to our thermodynamic calculations under these conditions, $\mathrm{La}$ and $\mathrm{Ni}^{\prime \prime}$ (from the phases $\mathrm{La}_{2} \mathrm{NiO}_{4}$ and $\mathrm{NiO}$ ) are soluble, whereas metallic $\mathrm{Ni}$ should remain solid (Figure 3). Therefore, we hypothesized that the low leaching yield obtained for nickel shows that $\mathrm{Ni}^{\prime \prime}$ has slow leaching $\mathrm{ki}$ netics at $\mathrm{pH} 5.5$, which consequently hinders the dissolution rate of REEs through the creation of a thicker diffusion layer than that at $\mathrm{pH} 3$.

XRD analysis of the solid leach residues obtained at $\mathrm{pH} 4$ and 5.5 at $40^{\circ} \mathrm{C}$ in $\mathrm{HCl}$ after $22 \mathrm{~h}$ of leaching (Figure $\mathrm{S} 3$ in the Supporting Information) reveals that they are composed of the same major phases as those present in the initial BM powder, namely, $\mathrm{Ni}, \mathrm{NiO}, \mathrm{CeO}_{2}$, and graphite.
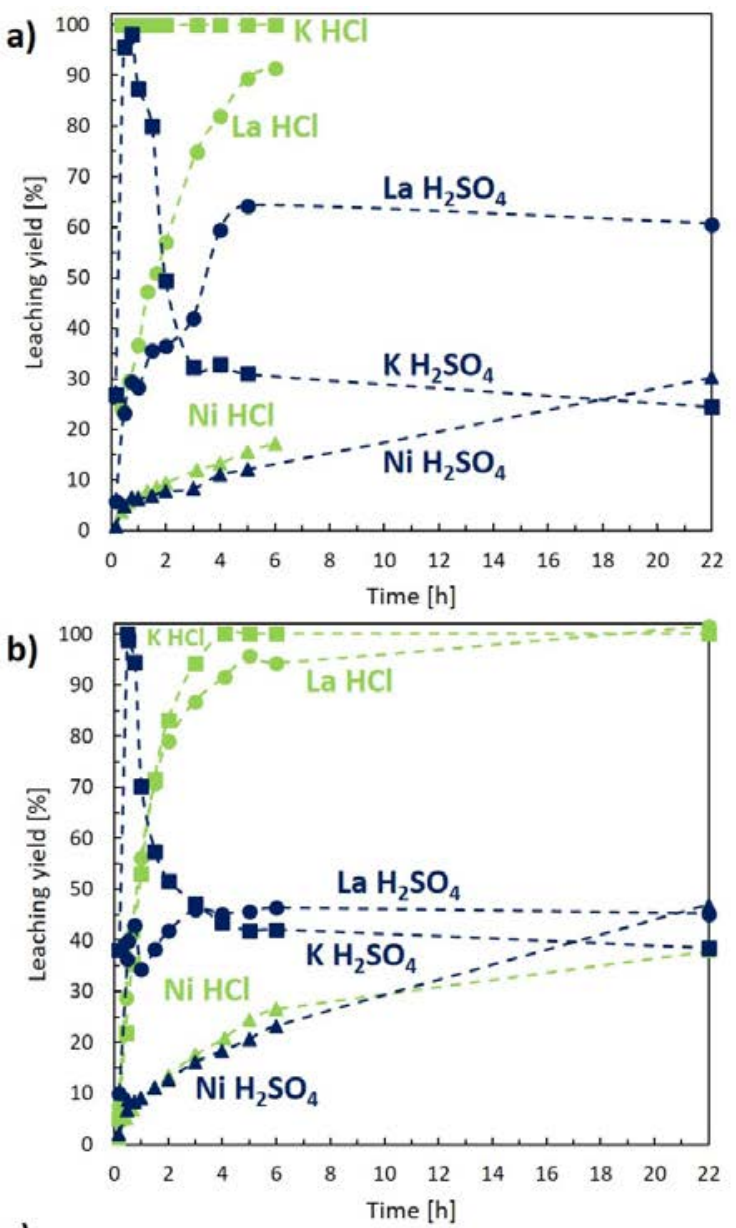

c)

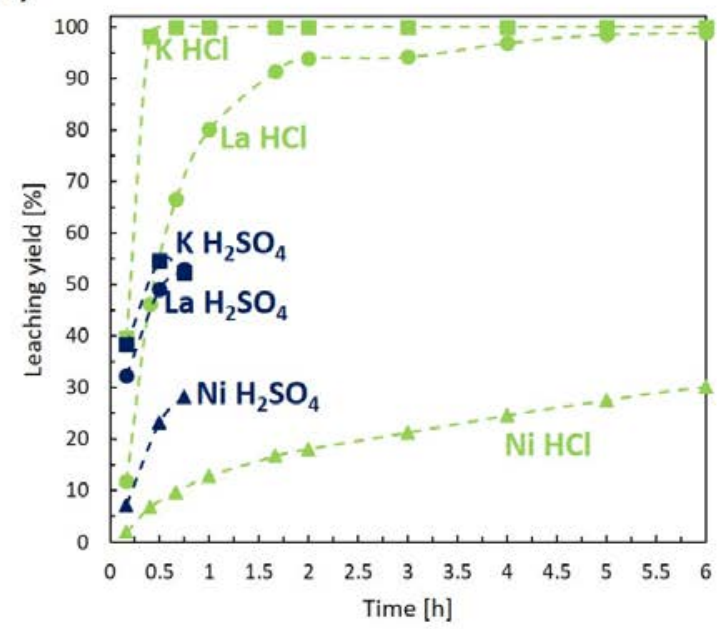

Figure 8. Evolution of the leaching yields of $\mathrm{K}$ (squares), La (circles), and $\mathrm{Ni}$ (triangles) in $\mathrm{HCl}$ (blue) and $\mathrm{H}_{2} \mathrm{SO}_{4}$ (green) at $\mathrm{pH} 3$ and at a) 25, b) 40, and c) $60^{\circ} \mathrm{C}$. 
The influence of the leaching agent $\left(\mathrm{HCl}\right.$ or $\left.\mathrm{H}_{2} \mathrm{SO}_{4}\right)$ on the dissolution of REEs, $\mathrm{Ni}$, and $\mathrm{K}$ has been studied at $\mathrm{pH} 3$ for temperatures ranging from 25 to $60^{\circ} \mathrm{C}$. Under these conditions, both acids are completely dissociated $\left(\mathrm{pK}_{\mathrm{a}}\left(\mathrm{HCl} / \mathrm{Cl}^{-}\right)=6.3, \mathrm{pK}_{\mathrm{a}}\left(\mathrm{H}_{2} \mathrm{SO}_{4} / \mathrm{HSO}_{4}{ }^{-}\right)=\right.$ 3.0, and $\mathrm{pK}_{\mathrm{a}}\left(\mathrm{H}_{2} \mathrm{SO}_{4} / \mathrm{SO}_{4}{ }^{2-}\right)=2.0$ at $\left.25^{\circ} \mathrm{C}\right)$.

Again, all REES ( $\mathrm{La}, \mathrm{Ce}, \mathrm{Nd}$, and $\mathrm{Pr}$ ) exhibit similar leaching behavior. Thus, only La is considered in the following discussion. As illustrated in Figure $8 \mathrm{a}$ and b, at $\mathrm{pH} 3$ and 25 or $40^{\circ} \mathrm{C}$, the leaching yield of $\mathrm{Ni}$ follows similar trends in $\mathrm{H}_{2} \mathrm{SO}_{4}$ and in $\mathrm{HCl}$ : yields of only 12.1 and $20.5 \%$ are obtained after $5 \mathrm{~h}$, respectively. At $60^{\circ} \mathrm{C}$, however, nickel is more reactive in $\mathrm{H}_{2} \mathrm{SO}_{4}$ than that in $\mathrm{HCl}$ (Figure $8 \mathrm{c}$ ): the same quantity is leached in $45 \mathrm{~min}$ in $\mathrm{H}_{2} \mathrm{SO}_{4}$ than that after $5 \mathrm{~h}$ in $\mathrm{HCl}$. It is worth noting that, for the experiment carried out in $\mathrm{H}_{2} \mathrm{SO}_{4}$ at $\mathrm{pH} 3$ and $60^{\circ} \mathrm{C}$, much greater acid consumption and gas production were observed than that at 25 or $40^{\circ} \mathrm{C}$. The increase in gas production, which is attributed to $\mathrm{H}_{2(\mathrm{~g})}$ generation, indicates

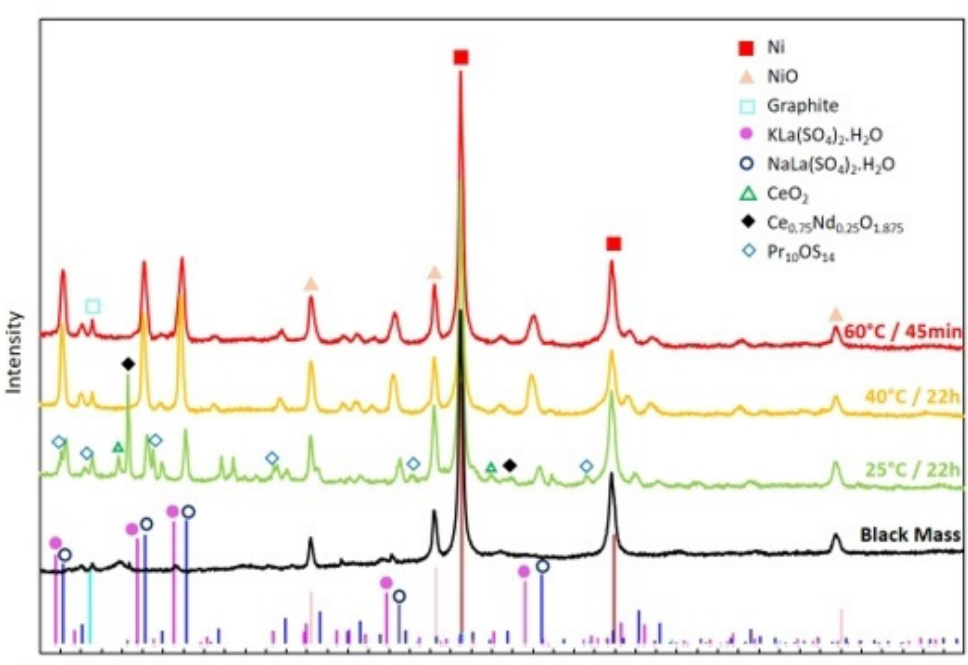

$\begin{array}{lllllllllllllllllllllll}24 & 26 & 28 & 30 & 32 & 34 & 36 & 38 & 40 & 42 & 44 & 46 & 48 & 50 & 52 & 54 & 56 & 58 & 60 & 62 & 64 & 66 & 68\end{array}$ $2 \theta\left({ }^{\circ}\right)$

Figure 9. Powder XRD spectra of the initial $\mathrm{BM}$ sample (black) and the solid leach resi dues after dissolution in $\mathrm{H}_{2} \mathrm{SO}_{4}$ at $\mathrm{pH} 3$ and $25^{\circ} \mathrm{C}$ for $22 \mathrm{~h}$ (green), at $\mathrm{pH} 3$ and $40^{\circ} \mathrm{C}$ for $22 \mathrm{~h}$ (yellow), and at $\mathrm{pH} 3$ and $60^{\circ} \mathrm{C}$ for $45 \mathrm{~min}$ (red). ditional diffraction peaks are observed (Figure S4 in the Supporting Information). This confirms the results of leaching yield analysis, which show that potassium precipitation does not start until all BM has been added, that is, after $24 \mathrm{~min}$ (Figure 8). As observed in Figure 9, the major phases of $\mathrm{Ni}$, $\mathrm{NiO}$, and graphite are still present, even after $22 \mathrm{~h}$ of leaching in $\mathrm{H}_{2} \mathrm{SO}_{4}$ for temperatures up to $60^{\circ} \mathrm{C}$. It is worth noting that the residue obtained after $22 \mathrm{~h}$ of leaching in $\mathrm{H}_{2} \mathrm{SO}_{4}$ at $\mathrm{pH} 3$ and $25^{\circ} \mathrm{C}$ contains minor phases of $\mathrm{Ce}_{0.75} \mathrm{Nd}_{0.25} \mathrm{O}_{1.875}$ and $\operatorname{Pr}_{10} \mathrm{OS}_{14}$, which are absent at $40^{\circ} \mathrm{C}$ (Figure 9). This shows that, in $\mathrm{H}_{2} \mathrm{SO}_{4}$, the precipitation behavior changes between 25 and $40^{\circ} \mathrm{C}$.

Furthermore, for all solid leach residues shown in Figure 9, a pristine phase appears that could be ascribed either to $\mathrm{NaLa}\left(\mathrm{SO}_{4}\right)_{2} \cdot \mathrm{H}_{2} \mathrm{O}$ or $\mathrm{KLa}\left(\mathrm{SO}_{4}\right)_{2} \cdot \mathrm{H}_{2} \mathrm{O}$. Because the $\mathrm{BM}$ powder does not contain $\mathrm{Na}$ and demineralized water is used for the experiments, we conclude that the peaks correspond to the phase $\mathrm{KLa}\left(\mathrm{SO}_{4}\right)_{2} \cdot \mathrm{H}_{2} \mathrm{O}$. Even if the XRD spectrum is not a perfect match because all peaks are slightly shifted to the right, with respect to the reference, this could be due to a mixed crystal composition. Indeed, several other lanthanide-potassium double sulfates $\left(\mathrm{K}_{3} \mathrm{M}\left(\mathrm{SO}_{4}\right)_{3}, \quad \mathrm{~K}_{6} \mathrm{M}_{4}\left(\mathrm{SO}_{4}\right)_{9}, \quad \mathrm{~K}_{7} \mathrm{M}_{3}\left(\mathrm{SO}_{4}\right)_{8}, \quad \mathrm{~K}_{5} \mathrm{M}\left(\mathrm{SO}_{4}\right)_{4}\right.$, and $\mathrm{K}_{6+3 n} \mathrm{M}_{4-n}\left(\mathrm{SO}_{4}\right)_{9} ; \mathrm{M}=\mathrm{La}, \mathrm{Ce}, \mathrm{Nd}$, or Pr) are reported in the literature. ${ }^{[14,43,44]}$ Porvali et al. studied the precipitation of REEs from strong sulfuric acid $\mathrm{NiMH}$ battery waste leachate by the addition of $\mathrm{Na}_{2} \mathrm{SO}_{4}$ and also observed a precipitate of mixed crystal composition with a structure close to that of the lanthanidealkali double sulfate. ${ }^{[14]}$

SEM observations of cross sections of the solid residue obtained after $22 \mathrm{~h}$ of leaching in $\mathrm{H}_{2} \mathrm{SO}_{4}$ at $\mathrm{pH} 3$ and $40^{\circ} \mathrm{C}$, and corresponding EPMA point analyses, are compiled in Figure $\mathrm{S} 5$ and Table S2 in the Supporting Information. Particles with core-shell structures and compositions similar to those obtained in $\mathrm{HCl}$ are detected (Figure S5 in the Supporting Inforalmost equivalent to that of the initial $\mathrm{BM}$ powder, and no adThe powder XRD spectra of the leach residues obtained
after 30 min of leaching in $\mathrm{H}_{2} \mathrm{SO}_{4}$ at $\mathrm{pH} 3$ and 25 or $40^{\circ} \mathrm{C}$ are

content with time, which is coherent with the results of PLS analysis. No traces of sodium were detected. The powder XRD spectra of the leach residues obtained
after 30 min of leaching in $\mathrm{H}_{2} \mathrm{SO}_{4}$ at $\mathrm{pH} 3$ and 25 or $40^{\circ} \mathrm{C}$ are almost equivalent to that of the initial BM powder, and no ad- 
mation, zones 1-3). As illustrated in Figure S5 in the Supporting Information, many precipitates were found around the undissolved particles (points 5-10) and contained, on average, 65.9 at $\%$ O, 12.7 at \% S, 8.5 at \% REEs, 8.3 at \% Ni, 3.4 at \% K, and 0.7 at $\%$ Co (Table S2 in the Supporting Information). These local chemical analyses confirm the conclusions drawn from XRD analysis that REEs and $\mathrm{K}$ have coprecipitated. They also provide evidence of the coprecipitation of nickel and cobalt, probably in the form of double Tutton's salts, such as $\mathrm{K}_{2} \mathrm{Ni}\left(\mathrm{SO}_{4}\right)_{2} \cdot 6 \mathrm{H}_{2} \mathrm{O}, \mathrm{K}_{2} \mathrm{Co}\left(\mathrm{SO}_{4}\right)_{2} \cdot 6 \mathrm{H}_{2} \mathrm{O}$, or $\mathrm{K}_{2} \mathrm{Ni}_{x} \mathrm{CO}_{1-x}\left(\mathrm{SO}_{4}\right)_{2} \cdot 6 \mathrm{H}_{2} \mathrm{O}$. ${ }^{[4-47]}$ The precipitation of nickel could at least partially explain the slow increase in aqueous nickel concentration measured in $\mathrm{H}_{2} \mathrm{SO}_{4}$ at $\mathrm{pH} 3$ at $40^{\circ} \mathrm{C}$. Although it is not possible to determine accurately the precipitate composition due to its complexity, it is assumed that the precipitates consist of a mixture of potassium-lanthanide double sulfates and $\mathrm{K}_{2} \mathrm{Ni}_{x} \mathrm{Co}_{1-x}\left(\mathrm{SO}_{4}\right)_{2} \cdot 6 \mathrm{H}_{2} \mathrm{O}$.

\section{Discussion}

The BM leaching mechanisms can be discussed thanks to a combination of all of our results (initial BM analyses, equilibrium calculations, evolution of the elemental concentrations in the PLS, and solid leach residue characterization by means of XRD, SEM, and EPMA). Whether in $\mathrm{HCl}$ or $\mathrm{H}_{2} \mathrm{SO}_{4}$, metallic $\mathrm{Ni}$, which is identified as such in Figure 1, zone 1, and originating from the cathode current collector, dissolves according to Equation (1). Gas generation was also observed during the experiments.

$\mathrm{Ni}_{(\mathrm{s})}+2 \mathrm{H}^{+} \rightarrow \mathrm{Ni}^{2+}+\mathrm{H}_{2(\mathrm{~g})}$

However, despite favorable thermodynamics, according to the $E_{\mathrm{h}}-\mathrm{pH}$ diagram at $\mathrm{pH} 3$ (Figure $3 \mathrm{~b}$ ), a large part of nickel in its metal form remains in the solid leach residue, as indicated in the X-ray diffractograms and by means of EPMA-WDS analyses (Figure 6, zone 5, and Table 3). Similar observations were reported by the groups of Larsson ${ }^{[13]}$ and Petranikova, ${ }^{[23]}$ who studied separately the leaching of anodes and cathodes from $\mathrm{NiMH}$ batteries in $\mathrm{HCl}$ media. These authors postulated that hydrogen produced during the acid attack of nickel metal [Eq. (1)] desorbed slowly from nickel surfaces. Based on electronic orbital considerations, Santos et al. also concluded that the adsorbed hydrogen intermediate species, $\mathrm{H}_{\mathrm{ad}}$ implied in the redox reaction (e.g., $\mathrm{H}_{\mathrm{ad}}+\mathrm{H}_{\mathrm{ad}}=\mathrm{H}_{2(\mathrm{~g})}$ or $\mathrm{H}^{+}+\mathrm{H}_{\mathrm{ad}}+\mathrm{e}^{-}=\mathrm{H}_{2(\mathrm{~g})}$ ) significantly slowed down the dissolution of metallic nickel in $\mathrm{HCl}$ media. ${ }^{[48]}$ For $\mathrm{H}_{2} \mathrm{SO}_{4}$ media, a possible explanation for hindered nickel leaching could be the formation of a passivation layer on the $\mathrm{Ni}$ surface in the form of $\mathrm{NiO}$ or $\mathrm{NiOOH}$, as reported by authors who have studied the anodic passivation of bulk $\mathrm{Ni}$ in $\mathrm{H}_{2} \mathrm{SO}_{4}$ media. ${ }^{[4-52]}$

Similarly, nickel contained in the $\mathrm{Ni} / \mathrm{Co}$ porous shell of $\mathrm{P} 5$ type particles and the $\mathrm{Ni} / \mathrm{Co} / \mathrm{O}$ core of some $\mathrm{P} 5$-type particles does not dissolve or has very slow leaching kinetics, which contributes to the selective leaching of REE relative to that of Ni. Indeed, in both acids, REE-containing particles (type P5), the core of which is mainly composed of lanthanum nickelates $\mathrm{La}_{2} \mathrm{NiO}_{4}$, exhibit selective leaching behavior, as evidenced by

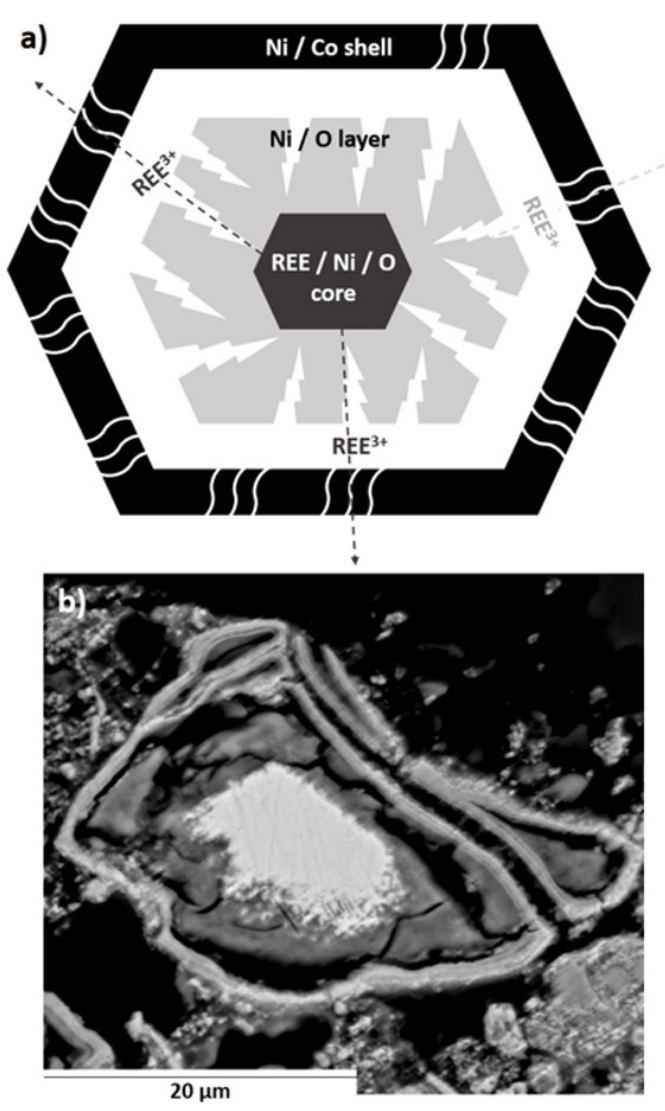

Figure 10. a) Schematic illustration of the proposed leaching mechanism of P5 type particles identified in Figure 2 in the initial BM sample powder, and b) the corresponding SEM BSE micrograph.

EPMA profiles such as that presented in Figure 7. The leaching rate of nickel is slower than that of REEs, resulting progressively in a hollow structure, as illustrated in Figure 10. It is suggested that dissolution of REEs [Eq. (2)] and their diffusion through the porous $\mathrm{Ni} / \mathrm{Co}$ shell results in a shrunken core rich in REEs, whereas an intermediate layer depleted of REEs, but rich in $\mathrm{Ni}$ and $\mathrm{O}$, remains and dissolves more slowly (Figure 10).

$\mathrm{La}_{2} \mathrm{NiO}_{4(\mathrm{~s})}+6 \mathrm{H}^{+} \rightarrow 2 \mathrm{La}^{3+}+\mathrm{NiO}_{(\mathrm{s})}+3 \mathrm{H}_{2} \mathrm{O}$

In $\mathrm{HCl}$ media, according to speciation obtained from thermodynamic calculations and consistent with experimental results, aqueous La forms soluble chloride compounds, such as $\mathrm{LaCl}^{2+}$ [Eq. (3)], whereas nickel dissolves mainly as $\mathrm{Ni}^{2+}$ and, to a lesser extent, $\mathrm{NiCl}^{+}$[Eq. (4)]. As a consequence, the leached elements remain in the aqueous phase.

$\mathrm{La}^{3+}+\mathrm{Cl}^{-} \rightarrow \mathrm{LaCl}^{2+}$

$\mathrm{Ni}^{2+}+\mathrm{Cl}^{-} \rightarrow \mathrm{NiCl}^{+}$

On the contrary, in $\mathrm{H}_{2} \mathrm{SO}_{4}$ media, leached REEs precipitate in the form of sulfates, $\mathrm{REE}_{2}\left(\mathrm{SO}_{4}\right)_{3}$; this behavior has also been reported elsewhere. ${ }^{[24,53,54]}$ Furthermore, Zelikman et al. explain that lanthanide sulfates tend to form lanthanide-alkali double 
salts in the presence of $\mathrm{K}_{2} \mathrm{SO}_{4}$ or $\mathrm{Na}_{2} \mathrm{SO}_{4}$, according to Equation (5), in which $\mathrm{M}=\mathrm{K}$ or $\mathrm{Na}$ and $\mathrm{REE}=\mathrm{La}, \mathrm{Ce}, \mathrm{Nd}$, or $\mathrm{Pr}^{[53]}$

$\operatorname{REE}_{2}\left(\mathrm{SO}_{4}\right)_{3}+\mathrm{M}_{2} \mathrm{SO}_{4} \rightarrow 2 \mathrm{REEM}\left(\mathrm{SO}_{4}\right)_{2} \cdot x \mathrm{H}_{2} \mathrm{O}$

Lokshin et al. measured the solubilities of double alkalimetal $(\mathrm{Na}, \mathrm{K})$-rare-earth $(\mathrm{La}, \mathrm{Ce})$ sulfates in solutions in sulfuric acid at $20^{\circ} \mathrm{C}$. For instance, at $20^{\circ} \mathrm{C}$ and low $\mathrm{H}_{2} \mathrm{SO}_{4}$ concentrations, the solubility of $\mathrm{KLa}\left(\mathrm{SO}_{4}\right)_{2} \cdot \mathrm{H}_{2} \mathrm{O}$ and $\mathrm{KCe}\left(\mathrm{SO}_{4}\right)_{2} \cdot \mathrm{H}_{2} \mathrm{O}$ is $0.015 \mathrm{~mol} \mathrm{~L}^{-1}$, which is close to the potassium concentration of $0.024 \mathrm{~mol} \mathrm{~L}^{-1}$ measured at $25^{\circ} \mathrm{C}$ after $3 \mathrm{~h}$, which is the point at which potassium precipitation stops (Figure $8 \mathrm{a}$ ). ${ }^{[55]}$ Thus, in $\mathrm{H}_{2} \mathrm{SO}_{4}$ media, part of the lanthanide ions form aqueous sulfate species [Eq. (6)], whereas others precipitate with $\mathrm{K}$ to form lanthanide-alkali metal double sulfates [Eq. (7)]. The main stable nickel species in $\mathrm{H}_{2} \mathrm{SO}_{4}$ media is $\mathrm{NiSO}_{4 \text { (aq) }}$ [Eq. (8)], but, as evidenced by our local characterization (Figure S5 and Table S2 in the Supporting Information), part of the nickel precipitates with K, according to Equation (9).

$$
\begin{aligned}
& 2 \mathrm{La}^{3+}+3 \mathrm{SO}_{4}{ }^{2-} \rightarrow \mathrm{La}_{2}\left(\mathrm{SO}_{4}\right)_{3(\mathrm{aq})} \\
& \mathrm{La}_{2}\left(\mathrm{SO}_{4}\right)_{3(\mathrm{aq})}+\mathrm{K}_{2} \mathrm{SO}_{4(\mathrm{aq})}+x \mathrm{H}_{2} \mathrm{O} \rightarrow 2 \mathrm{KLa}\left(\mathrm{SO}_{4}\right)_{2} \cdot x \mathrm{H}_{2} \mathrm{O}_{(\mathrm{s})} \\
& \mathrm{Ni}^{2+}+\mathrm{SO}_{4}{ }^{2-} \rightarrow \mathrm{Ni}\left(\mathrm{SO}_{4}\right)_{(\mathrm{aq})} \\
& \mathrm{Ni}\left(\mathrm{SO}_{4}\right)_{(\mathrm{aq})}+\mathrm{K}_{2} \mathrm{SO}_{4(\mathrm{aq})}+6 \mathrm{H}_{2} \mathrm{O} \rightarrow \mathrm{K}_{2} \mathrm{Ni}\left(\mathrm{SO}_{4}\right)_{2} \cdot 6 \mathrm{H}_{2} \mathrm{O}
\end{aligned}
$$

\section{Conclusions}

An industrial sample of spent NiMH battery powder, which was obtained by the thermomechanical treatment of a batch of $600 \mathrm{~kg}$, was characterized for chemical and structural properties. Chemical analysis revealed that the sample powder was mainly composed of $45 \mathrm{wt} \% \mathrm{Ni}, 15 \mathrm{wt} \%$ REEs, and $13 \mathrm{wt} \% \mathrm{O}$, whereas XRD analysis demonstrated that the major crystalline phases consisted of $\mathrm{Ni}$ and $\mathrm{NiO}$. A novel result was the quantitative EPMA-WDS analyses of cross sections of the powders, which helped to provide an overall description that was consistent with the initial battery constitution. Indeed, particles containing 97.4 at\% Ni corresponded to the metallic nickel mesh of the cathode current collector and porous spherical particles rich in $\mathrm{Ni}$ and $\mathrm{Co}$ came from the cathode active mass. An interesting result was the identification of mischmetal particles with core-shell structures: at the core, the $(\mathrm{Ni}, \mathrm{Co}, \mathrm{Mn}, \mathrm{Al}) /(\mathrm{La}$, $\mathrm{Ce}, \mathrm{Nd}, \mathrm{Pr}$ ) molar ratio was 4.5 , whereas the dense shell layer contained 1.35 times more $\mathrm{Ni}$ and $\mathrm{Co}$ than that in the core. Moreover, an oxide layer rich in REEs surrounded this dense shell. We attributed such particle morphology to NiMH battery aging mechanisms after cycling in $\mathrm{KOH}$ electrolyte, in which corrosion subscales concentrated in $\mathrm{Ni}$ and $\mathrm{Co}$ and REE hydroxide structures were known to form around the mischmetal particles.

In view of a sustainable recycling process, a parametric study was carried out in a $10 \mathrm{~L}$ pilot-scale reactor to assess the influence of $\mathrm{pH}(3-5.5)$, temperature $\left(25-60^{\circ} \mathrm{C}\right)$, and type of acid $\left(\mathrm{HCl}\right.$ or $\left.\mathrm{H}_{2} \mathrm{SO}_{4}\right)$ on the leaching mechanisms of $\mathrm{Ni}$ and REEs contained in the industrial battery powders.

Partial selectivity was evidenced in $\mathrm{HCl}$ at $\mathrm{pH} 3$ for all temperatures. For instance, at $25^{\circ} \mathrm{C}, 91.6 \%$ of $\mathrm{La}$ and $17.2 \%$ of $\mathrm{Ni}$ leached after $6 \mathrm{~h}$, leading to an aqueous La/Ni molar ratio of 5.31. In $\mathrm{H}_{2} \mathrm{SO}_{4}$ media, a similar selective dissolution occurred at 25 and $40^{\circ} \mathrm{C}$, whereas nickel dissolution was enhanced at $60^{\circ} \mathrm{C}$. However, potassium present in the initial battery powder (about $2 \mathrm{wt} \% \mathrm{~K}$ ) led to the in situ precipitation of REEs in the form of lanthanide-potassium double sulfates, as well as the precipitation of nickel and cobalt double salts; thus reducing their overall dissolution yields.

One of the reasons for the selective dissolution of REEs, with respect to $\mathrm{Ni}$, was due to the kinetic inhibition of nickel metal leaching, in both $\mathrm{HCl}$ and $\mathrm{H}_{2} \mathrm{SO}_{4}$, as already reported in several studies. In the present work, thanks to local EPMA analyses of the solid leach residues, we also showed that specific leaching mechanism occurred in the core-shell mischmetal particles, in both acid media. The $\mathrm{Ni}$ - and Co-rich shell, originating from a corrosion subscale, remained undissolved, even after $22 \mathrm{~h}$ of leaching. The leaching mechanism of the interior of such particles was of the "shrinking core" type, in which the leaching rate of REEs was faster than that of $\mathrm{Ni}$. As dissolution proceeded, this resulted in a concentration gradient inside the core of the particles. These findings highlight the influence of battery anode aging phenomena on the leaching mechanisms of $\mathrm{Ni}$ and REEs from industrial samples of spent NiMH battery powders.

\section{Experimental Section}

\section{Initial raw material characterization}

The BM powder was characterized for chemical content, phase determination, and morphological features. The material was mineralized at $250^{\circ} \mathrm{C}$ for $2 \mathrm{~h}$ in aqua regia (mixture of $\mathrm{HCl} 37 \%$ and $\mathrm{HNO}_{3}$ $65 \%$ in a 1:1 ratio), with a S/L mass ratio of $10 \%$; a cooling system was used to condense vapors. The elemental content was determined by means of ICP-OES (PerkinElmer Optima 8300), for the following elements: $\mathrm{Al}, \mathrm{Cd}, \mathrm{Ce}, \mathrm{Co}, \mathrm{Cu}, \mathrm{Fe}, \mathrm{La}, \mathrm{Li}, \mathrm{Mn}, \mathrm{Nd}, \mathrm{Ni}, \mathrm{Pr}, \mathrm{Zn}, \mathrm{K}$, and $\mathrm{Na}$. Oxygen and carbon contents were measured by using instrumental gas analyzers (IGAs) equipped with IR detectors (EMGA 620 W LECO for oxygen and EMIA 820 V HORIBA for carbon). Phase composition was determined by means of powder XRD on a D8 BRUKER instrument in the $\theta / 2 \theta$ configuration and $\mathrm{Cu}_{\mathrm{k \alpha}}$ radiation ( $2 \theta$ range of $2080^{\circ}$, with a wavelength of $1.5418 \AA$ ). Cross sections of the solid material were prepared by embedding the powders in a nonconducting thermosetting resin (PolyFast, STRUERS) for hot molding (Mecapress 3, PRESI) and diamond-polished down to $1 \mu \mathrm{m}$ (Mecatech 234, PRESI). Semiquantitative analyses of the cross sections were carried out by using a scanning electron microscope field-emission gun (SEM-FEG, JEOL JSM 7100F) equipped with an EDX Oxford ASDD X-Max detector. Quantitative analyses of the cross sections were performed with an EPMA (CAMECA SXFive FE) equipped with WDS detectors.

\section{Pilot setup of the leaching experiments}

The leaching tests were performed in a $10 \mathrm{~L}$ jacketed glass reactor equipped with a three-baffle mechanical stirrer. A constant mixing 
rate of $400 \mathrm{rpm}$ ensured the suspension of all particles. The temperature inside the reactor was regulated by using a HUBER Ministat 240 instrument. A mass of $1.2 \mathrm{~kg}$ of BM powder was added at a constant rate of $50 \mathrm{~g} \mathrm{~min}^{1}$ in an initial volume of $8 \mathrm{~L}$ of demineralized water, leading to an initial S/L ratio of $15 \%$; the starting time $\left(\begin{array}{ll}t & 0\end{array}\right)$ of the experiment was the beginning of BM addition. The $\mathrm{pH}$ of the solution in the reactor was regulated in the range of $3<$ $\mathrm{pH}<5.5$, by using a PID controller connected to a pump and a stock container of leaching agent. Relative $\mathrm{pH}$ standard deviations were lower than $\pm 4 \%$ for all experiments. $\mathrm{HCl}(12 \mathrm{M} / 12 \mathrm{~N})$ or $\mathrm{H}_{2} \mathrm{SO}_{4}$ $(6 \mathrm{M} / 12 \mathrm{~N})$ were used as leaching agents (reagent grade) for $\mathrm{pH}$ adjustment and acid consumption was followed by measuring the mass of acid with a balance. The effects of three process parameters on leaching yields and mechanisms were studied up to $22 \mathrm{~h}$ : the influence of $\mathrm{pH}(35.5)$ at $40^{\circ} \mathrm{C}$ in $\mathrm{HCl}$, and the influence of temperature $\left(2560^{\circ} \mathrm{C}\right)$ and type of acid $\left(\mathrm{HCl}\right.$ or $\left.\mathrm{H}_{2} \mathrm{SO}_{4}\right)$ at pH 3 . At the end of the runs, the remaining solid leach residue was filtered from the PLS by using a pneumatic filter press and the PLS was collected for further treatment.

To follow the evolution of the leaching yields, samples $(5 \mathrm{~mL})$ were taken at periodic time intervals, filtered through $0.45 \mu \mathrm{m}$ syringe filters, and analyzed by means of ICP-OES. The resulting leaching yield for a given element, $i$, at time $t, L Y_{i}(t)$, is calculated according to Equation (10):

$L Y_{i}(t) \quad 100 \frac{C_{i}(t) V_{\text {tot }}(t)}{m_{\mathrm{BM}} W_{i}}$

in which $C_{i}(t)$ is the concentration of element $i$ in the sample at time $t$ (in $\left.\mathrm{gL}^{1}\right), V_{\text {tot }}(t)$ is the total volume of solution $\left(\mathrm{H}_{2} \mathrm{O}+\right.$ added acid, in L), $m_{\mathrm{BM}}$ is the initial mass of BM powder (in $\mathrm{g}$ ), and $w_{i}$ is the mass fraction of element $i$ in the initial BM powder.

In addition, for some experiments, four samples $(\approx 150 \mathrm{~mL})$ were extracted at different times and filtered by using a Büchner system, to 1) measure the $S / L$ ratio evolution; and 2) characterize the solid residues by means of XRD, SEM-FEG, EPMA, and ICP-OES. The consistency of the overall elementary mass balance was verified for one set of conditions $\left(\mathrm{H}_{2} \mathrm{SO}_{4}(6 \mathrm{M}), \mathrm{pH} 3,40^{\circ} \mathrm{C}\right.$, repeated twice) by comparing the analysis of the solid samples extracted with the Büchner system, the analysis of the aqueous solution, and the initial BM composition.

\section{Thermodynamic calculations}

Thermodynamic calculations were carried out thanks to the geochemical software PHREEQC operated with PHREEPlot. ${ }^{[56]}$ The extended Debye Hückel b-dot equation of the LLNL model was used to calculate aqueous activity coefficients. ${ }^{[56]}$ Thermodynamic data were taken from the 2017 version of the Thermoddem database ${ }^{[57]}$ and completed to account for the thermodynamic properties of solid phases $\left(\mathrm{La}(\mathrm{OH})_{3},{ }^{[58]} \mathrm{LaNi}_{5}{ }^{[59]}\right.$ and $\left.\mathrm{La}_{2} \mathrm{NiO}_{4}{ }^{[41]}\right)$ and aqueous lanthanide chloride compounds $\left(\mathrm{LaCl}_{2}{ }^{+}, \mathrm{LaCl}^{2+}, \mathrm{LaCl}_{3}\right.$, and $\left.\mathrm{LaCl}_{4}\right),{ }^{[60,61]}$ valid in the temperature range $2590^{\circ} \mathrm{C} . E_{\mathrm{h}} \mathrm{pH}$ speciation diagrams were calculated at 25,40 , and $60^{\circ} \mathrm{C}$, with La and Ni concentrations corresponding to a $15 \mathrm{wt} \% \mathrm{~S} / \mathrm{L}$ ratio ( $\mathrm{S}$ is the solid $\mathrm{BM}$ and $L$ is the $\mathrm{HCl} \mathrm{H}_{2} \mathrm{O}$ liquid phase).

\section{Acknowledgements}

We wish to thank Sophie Gouy and Philippe De Parseval from the Centre de Micro-caractérisation Raimond Castaing for various
EPMA analyses, as well as Marie-Line de Solan-Bethmale from the Laboratoire de Génie Chimique (LGC) for the SEM analyses, and Cédric Charvillat from the Centre Interuniversitaire de Recherche et d'Ingénierie des Matériaux (CIRIMAT) for the powder XRD measurements.

\section{Conflict of interest}

The authors declare no conflict of interest.

Keywords: alkali metals • electrochemistry • nanoparticles nickel $\cdot$ rare earths

[1] Deloitte Sustainability, British Geological Survey, Minières, Bureau de Re cherches Géologiques et Minières, Research, Netherlands Organisation for Applied Scientific, Study on the Review of the List of Critical Raw Ma terials, Brussels, 2017.

[2] L. E. O. C. Rodrigues, M. B. Mansur, J. Power Sources 2010, 195, 3735 3741.

[3] P. Meshram, B.D. Pandey, T. R. Mankhand, Waste Manage. 2016, 51 196203.

[4] C. Pillot, The Rechargeable Battery Market and Main Trends 20162025 2017.

[5] Trinomics, Study in Support of Evaluation of the Directive 2006/66/EC on Batteries and Accumulators and Waste Batteries and Accumulators, 2014.

[6] European Union, European Innovation Partnership on Raw Materials: Raw Materials Scoreboard, 2016.

[7] J. J. M. Nelson, E. J. Schelter, Inorg. Chem. 2019, 58, 979990.

[8] ADEME, 2017, 1 146.

[9] P. Subir, Understanding the Material Science of Battery We Use Every Day, found under http://www.tsijournals.com/articles/understanding the ma terial science of battery we use everyday.html.

[10] J. Nan, D. Han, M. Yang, M. Cui, J. Electrochem. Soc. 2006, 153, A101.

[11] S. Al Thyabat, T. Nakamura, E. Shibata, A. lizuka, Miner. Eng. 2013, 45, 4 17.

[12] V. Innocenzi, F. Vegliò, J. Power Sources 2012, 211, 184191.

[13] K. Larsson, C. Ekberg, A. Ødegaard Jensen, Waste Manage. 2013, 33, 689698.

[14] A. Porvali, B. P. Wilson, M. Lundström, Waste Manage. 2018, 71, 381 389.

[15] K. Young, B. Chao, Y. Liu, J. Nei, J. Alloys Compd. 2014, 606, 97104.

[16] A. Fernandes, J. C. Afonso, A. J. B. Dutra, Hydrometallurgy 2013, 133, 3743.

[17] N. Tzanetakis, K. Scott, J. Chem. Technol. Biotechnol. 2004, 79, 919926.

[18] K. Korkmaz, M. Alemrajabi, Å. C. Rasmuson, K. M. Forsberg, Metals 2018 8, 1062.

[19] P. Zhang, T. Yokoyama, O. Itabashi, Y. Wakui, T. M. Suzuki, K. Inoue, Hy drometallurgy 1998, 50, 6175.

[20] X. Yang, J. Zhang, X. Fang, J. Hazard. Mater. 2014, 279, 384388.

[21] F. Holmberg, Recycling of Nickel Metal Hydride (NiMH) Batteries: Charac terization and Recovery of Nickel, AB5 Alloy and Cobalt, Chalmers Univer sity of Technology, 2017.

[22] S. Luidold, H. Antrekowitsch, EP 2444507 B1, 2012.

[23] M. Petranikova, I. Herdzik Koniecko, B. M. Steenari, C. Ekberg, Hydrome tallurgy 2017, 171, 128141.

[24] L. Li, S. Xu, Z. Ju, F. Wu, Hydrometallurgy 2009, 100, 4146.

[25] M. A. Rabah, F. E. Farghaly, M. A. Abd El Motaleb, Waste Manage. 2008, 28, 11591167.

[26] L. Pietrelli, B. Bellomo, D. Fontana, M. R. Montereali, Hydrometallurgy 2002, 66, 135139.

[27] L. Pietrelli, B. Bellomo, D. Fontana, M. Montereali, Waste Manage. 2005, 25, 221226.

[28] P. Meshram, B. D. Pandey, T. R. Mankhand, Hydrometallurgy 2015, 158, 172179.

[29] D. A. Bertuol, A. M. Bernardes, J. A. S. Tenório, J. Power Sources 2009 193, 914923. 
[30] A. R. Alonso, E. A. Perez, G. T. Lapidus, R. M. Luna Sanchez, Hydrometal lurgy 2014, 1, 277289.

[31] P. Zhang, T. Yokoyama, O. Itabashi, Y. Wakui, T. M. Suzuki, K. Inoue, J. Power Sources 1999, 77, 116122.

[32] C. Liu, Y. Deng, J. Chen, D. Zou, W. Su, Ind. Eng. Chem. Res. 2017, 56, 75517558

[33] A. Porvali, V. Agarwal, M. Lundström, Mining, Metall. Explor. 2019, 36, 979991.

[34] P. Leblanc, B. Knosp, C. Jordy, P. Blanchard, J. Electrochem. Soc. 1998 145,860863

[35] P. Bäuerlein, C. Antonius, J. Löffler, J. Kümpers, J. Power Sources 2008 176, 547554

[36] F. Maurel, B. Knosp, M. Backhaus Ricoult, J. Electrochem. Soc. 2000, 147, 7886.

[37] D. Chartouni, F. Meli, A. Züttel, K. Gross, L. Schlapbach, J. Alloys Compd. 1996, 241, 160166

[38] M. Ikoma, K. Komori, S. Kaida, C. Iwakura, J. Alloys Compd. 1999, 284, 9298.

[39] X. Zhou, K. Young, J. West, J. Regalado, K. Cherisol, J. Alloys Compd. 2013, 580, S373 S377.

[40] L. Schlapbach, A. Seiler, H. C. Siegmann, F. Stucki, J. Less Common Met. 1980, 73, 145160.

[41] M. Zinkevich, F. Aldinger, J. Alloys Compd. 2004, 375, 147161.

[42] S. A. Hosseini, S. Raygan, A. Rezaei, A. Jafari, J. Environ. Chem. Eng. 2017, 5, 39223929

[43] M. S. Wickleder, Chem. Rev. 2002, 102, 20112087.

[44] P. A. Degtiarev, J. Less Common Met. 1979, 68, 107110.

[45] V. Manomenova, E. Rudneve, A. Voloshin, Russ. Chem. Rev. 2016, 85, 585609.

[46] A. E. Voloshin, V. L. Manomenova, E. B. Rudneva, N. A. Vasilyeva, V. M. Masalov, A. A. Zhokhov, G. A. Emelchenko, J. Cryst. Growth 2018, 500, 98103.

[47] N. A. Vasilyeva, D. Nuzhdin, M. A. Faddeev, V. V. Grebenev, V. A. Lykov, A. E. Voloshin, Crystallogr. Rep. 2016, 61, 304307.
[48] E. Santos, P. Hindelang, P. Quaino, E. N. Schulz, G. Soldano, W. Schmick ler, ChemPhysChem 2011, 12, 22742279.

[49] T. Du, A. Vijayakumar, K. B. Sundaram, V. Desai, Microelectron. Eng. 2004 75, 234241

[50] A. E. Sanli, A. Aytac, ECS Trans. 2012, 42, 322.

[51] M. Itagaki, H. Nakazawa, K. Watanabe, K. Noda, Corros. Sci. 1997, 39, 901911.

[52] N. Sato, G. Okamoto, J. Electrochem. Soc. 1963, 110, 605614

[53] A. N. Zelikman, O. E. Krein, G. V. Samsonov, Metallurgy of Rare Metals, 1964

[54] D. S. Todorovsky, M. M. Milanova, N. L. Minkova, C. Balarev, Monatsh. Chem. 1993, 124, 673679.

[55] E. P. Lokshin, O. A. Tareeva, K. G. Ivlev, T. G. Kashulina, Russ. J. Appl. Chem. 2005, 78, 10581063.

[56] D. L. Parkhurst, C. A. J. Appelo, PHREEQC (Version 3) A Computer Pro gram for Speciation, Batch Reaction, One Dimensional Transport, and In verse Geochemical Calculations, 2013.

[57] P. Blanc, A. Lassin, P. Piantone, M. Azaroual, N. Jacquemet, A. Fabbri, E. C. Gaucher, Appl. Geochem. 2012, 27, 21072116.

[58] C. Ekberg, P. L. Brown, Hydrolysis of Metal lons, Wiley VCH, Weinheim, 2016.

[59] N. P. Gorbachuk, V. B. Muratov, Powder Metall. Met. Ceram. 2005, 44, 467471.

[60] J. Haas, E. Shock, D. Sassani, Geochim. Cosmochim. Acta 1995, 59, 4329 4350.

[61] E. L. Shock, H. C. Helgeson, Geochim. Cosmochim. Acta 1988, 52, 2009 2036. 